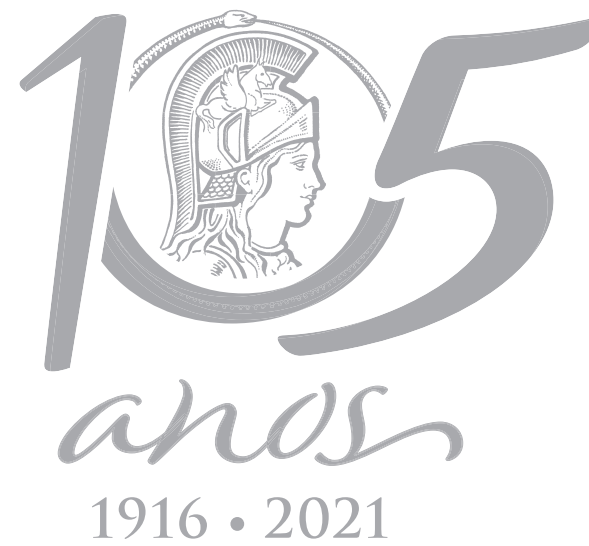

$1916 \cdot 2021$

\title{
GEOSCIENCES
}

\section{Chemical classification of common volcanic rocks based on degree of silica saturation and $\mathrm{CaO} / \mathrm{K}_{2} \mathrm{O}$ ratio}

\author{
JOÃO O.S. SANTOS \& LÉO A. HARTMANN
}

\begin{abstract}
Modal classifications of common volcanic rocks are expensive, difficult, or impossible to attain. As a consequence, these rocks are classified using the chemical composition. However, existing classificatory diagrams are unable to identify all 16 families of common volcanic rocks; the most used is the total alkali-silica (TAS) diagram that identifies six families. Rocks not in the TAS diagram are misclassified with other rock names; their names are evolving to extinction, e.g. latite and rhyodacite. Some diagrams use $\mathrm{Na}_{2} \mathrm{O}$, which is a complicating element rather than discriminant. $\mathrm{Na}_{2} \mathrm{O}$ is present both in alkali feldspar and plagioclase making difficult the separation of the amount associated to either feldspar. Silicon, potassium, and calcium are the three major elements with highest variations among volcanic rocks. They are selected for use in two new diagrams confronting $\mathrm{CaO} / \mathrm{K}_{2} \mathrm{O}$ ratio with $\mathrm{K}_{2} \mathrm{O}$ content ( $\mathrm{KCK}$ diagrams). One diagram is designed for saturated (intermediate) rocks (quartz <5 vol.\%) and the other for oversaturated (acid) volcanic rocks (quartz $>5 \%$ ). These diagrams are tested using compositions of volcanic rocks from Uatumã magmatism in the Amazon Craton and also by plotting compositions of rocks from type-localities and the world averages. The proposed limits between rock families agree with plotted rock compositions. The KCK diagrams are an alternative to existing diagrams to classify volcanic rocks.
\end{abstract}

Key words: Chemical classification, volcanic rocks, silica saturation, Uatumã volcanism.

\section{INTRODUCTION}

The classification of volcanic rocks is a challenge where the optical identification of their minerals is often not possible considering the presence of very fine crystals $(<0.125 \mathrm{~mm}$ ) or even glassy matrix. Common volcanic rocks (not including ultrabasic effusive, foidite, lamprophyre, carbonatite, and melilite) are classified and named based on their degree of silica saturation and their proportion of K-feldspar and plagioclase (Shand 1913, Rittmann 1952, Streckeisen 1978). Modal compositions, however, are difficult and expensive to obtain even using modern Scanning Electron Microscopes. In addition, the examined volume in one thin section is insignificant compared with the volume of the whole rock used in chemical analysis. Another difficulty encountered in modal analyses is the determination of the correct compositional variation of feldspars. Knowing the ratio of perthites in orthoclase, sanidine, or microcline (rare in volcanic rocks) is critical to know the amount of albite (and $\mathrm{Na}_{2} \mathrm{O}$ ) related to either alkali feldspar or plagioclase. The difficulty increases when sub-microscopic cryptoperthites are present (Brown \& Willaime 1974, Yund \& Chapple 1980). Volcanic plagioclase typically develops compositional zoning during growth where the core was formed at higher temperature and the rim at lower temperature (Haase et al. 1980). The core has less sodium 
(proportion of albite) and more calcium (proportion of anorthite). For example, andesite commonly has plagioclase phenocrysts composed of labradorite core and andesine rim (Gill 1981, Izbekov et al. 2002). Reverse zoning is also a limiting factor by which calcic plagioclase surrounds a sodic core, as in many andesites (Gill 1981, Wada 1985).

Considering these difficulties, modal classifications are often replaced by diagrams based on chemical composition. These classifications are widely used based in several diagrams. Common volcanic rocks are organized in 16 families of rocks: alkali feldspar rhyolite (2), rhyolite (3a), rhyodacite (3b), dacite ( 4 and 5), quartz alkali feldspar trachyte $\left(6^{*}\right)$, alkali feldspar trachyte (6), trachyte (7), quartz trachyte $\left(7^{\star}\right)$, latite $(8)$, quartz latite $\left(8^{\star}\right)$, trachyandesite (9), quartz trachyandesite $\left(9^{*}\right)$, andesite and basalt (10), quartz andesite and quartz basalt $\left(10^{*}\right)$. This naming and numbering are the same as the QAP diagram of Streckeisen (1979), except for quartz andesite and quartz basalt, included by Streckeisen (1979) and IUGS (Le Maitre et al. 2002) in basalt and andesite. These 16 families of rocks have direct correspondence to their plutonic equivalents: e.g. andesite is the volcanic equivalent of diorite and latite is the volcanic equivalent of monzonite. The existing and widely used diagrams of chemical classification of volcanic rocks are unable to identify the 16 major families of common volcanic rocks. They also fail to maintain correspondence between names of volcanic and equivalent plutonic rocks. Some common volcanic rocks are disappearing from the literature and moving to extinction, and this is because the diagrams do not identify the rocks. This is the case of latite and rhyodacite, two major rock types.

Nearly all diagrams based on major elements include sodium or $\mathrm{Na}_{2} \mathrm{O}$ (Jensen 1976, Cox et al. 1979, De La Roche et al. 1980, Debon \& Lefort
1983, Middlemost 1985). This element (or sodium oxide) is present in either plagioclase or alkali feldspar; sodium complicates the classification rather than clarifying. Using Irvine \& Baragar (1971) as an example, all sodium (normative albite) is associated with plagioclase. Some or much $\mathrm{Na}_{2} \mathrm{O}$ is actually either in the structure of K-feldspar (perthite) or pure albite. An alkali feldspar rhyolite or rhyolite with either perthite or pure albite is misclassified as dacite.

We propose two new diagrams $(\mathrm{KCK}=\mathrm{CaO} /$ $\mathrm{K}_{2} \mathrm{O}$ versus $\mathrm{K}_{2} \mathrm{O}$ ) to classify common volcanic rocks. They are based on several sets of data, including the composition of Uatumã volcanic rocks from the Amazon Craton, rocks from type localities (Tröger 1935), and world averages from Nockolds (1954) and Le Maitre (1976). Chemical data from pyroclastic rocks are not included; they represent about 25 vol.\% of Uatumã volcanism. We use older datasets because most published volcanic names after the early 1980's were based on the TAS (Total Alkali-Silica - Cox et al. 1979, Le Bas et al. 1986, Le Maitre et al. 2002) diagram, which recognizes six out of the existing 16 families of volcanic rocks.

\section{MATERIALS AND METHODS}

Chemical compositions (major and minor elements) of volcanic rocks from the of Amazon Craton were selected for this study. Analyses and classifications are from the 1970 decade and are pre-TAS as required for our testing. Data are from published and unpublished reports of Brazilian Government institutions (Table I). A large number $(n=218)$ of analyses (Table II) were selected from samples of calc-alkaline volcanic rocks related to the Uatumã Supergroup (Albuquerque 1922, Ferreira 1959, Ramgrab \& Santos 1974, Santos 1984). 
Analyses in Table I were performed at the Laboratory of Chemical Analyses of Minerals and Rocks of Geosciences Institute of UFRGS (Federal University of Rio Grande do Sul, Porto Alegre, Brazil) and in LAMIN (Mineralogical Laboratory of CPRM, Rio de Janeiro, Brazil).

\section{Sample preparation and data processing}

Several procedures are suggested in the classification of volcanic rocks. These steps or most of them are useful for classifications. The adopted sequence of procedures in this study is the following:

a) Select fresh and representative samples;

b) Avoid samples with veins, xenoliths, and hydrothermal minerals;

c) Observe thin sections for mineralogy and texture of the rock;

d) Perform chemical analyses of major and trace elements, including $\mathrm{H}_{2} \mathrm{O}, \mathrm{SO}_{2}$ and $\mathrm{CO}_{2}$; e) Only select data with totals ranging from $98 \%$ to $102 \%$. Normalize to 100 wt.\%;

f) Correct the $\mathrm{Fe}_{2} \mathrm{O}_{3} / \mathrm{FeO}$ ratio following Coombs (1963) and Chayes (1966);

g) Calculate the normative composition (CIPW, Cross et al. 1902);

h) Separate normative olivine- and nephelinerich rocks (ultrabasic and alkaline);

i) Calculate the $\mathrm{NCl}$ (Normative Colour Index: $h y+d i+o l+m t+i l+h m)$;

j) Calculate the NPC (Normative Plagioclase Composition): [100An/ (An+Ab+5/3Ne)];

k) Plot the NPC (Normative Composition of Plagioclase versus the $\mathrm{NCl}$ (Normative Colour Index, Irvine \& Baragar 1971) to separate basaltic from andesitic rocks;

l) Group the data other than basalt in three sets according to their normative quartz (0-5 vol.\%, saturated; 5-20\%, moderately oversaturated and $>20 \%$, oversaturated). Rocks with Nqtz = zero and having normative

Table I. Sources of chemical analysis of volcanic rocks, from government reports.

\begin{tabular}{|c|c|c|c|c|c|c|c|}
\hline Source & Project & Location & Unit & Age-Ma & \multicolumn{2}{|c|}{$\mathbf{n}$} & reference \\
\hline \multirow{3}{*}{$\begin{array}{l}\text { DNPM- } \\
\text { RADAM }\end{array}$} & \multirow{3}{*}{ RADAM } & NA.20-NB.20 & Surumu & 1985 & 10 & \multirow{3}{*}{34} & Montalvão et al. (1975) \\
\hline & & SA.21 & Iricoumé & 1860 & 14 & & Araújo et al. (1976) \\
\hline & & NA.21 & Surumu & 1985 & 10 & & Oliveira et al. (1975) \\
\hline \multirow{4}{*}{ DNPM-CPRM } & Jamanxim & SB.21-X-C & Iriri & 1870 & 12 & \multirow{4}{*}{58} & Pessoa et al. (1977) \\
\hline & Sulfetos Uatumã & SA.21-V & Iricoumé & 1860 & 28 & & Veiga Jr et al. (1979) \\
\hline & $\begin{array}{l}\text { Molibdênio } \\
\text { Roraima }\end{array}$ & NB.20-Z-D & Surumu & 1985 & 12 & & Melo et al. (1978) \\
\hline & Tajajós-Sucunduri & $\begin{array}{l}\text { SB.20-Z } \\
\text { SB.21-Y }\end{array}$ & Iriri & 1870 & 6 & & Bizzinella et al. (1980) \\
\hline \multirow{3}{*}{$\begin{array}{l}\text { SUDAM- } \\
\text { GEOMITEC }\end{array}$} & Tapajós-Maués & SB.21 & Iriri & 1870 & 6 & \multirow{3}{*}{126} & SUDAM-GEOMITEC (1976) \\
\hline & \multirow{2}{*}{ Tapajós-Jamanxim } & \multirow{2}{*}{ SB.21-X-C } & Iriri & 1870 & 55 & & SUDAM-GEOMINERAÇÃO (1972) \\
\hline & & & Iriri & 1870 & 65 & & SUDAM-GEOMITEC (1972) \\
\hline
\end{tabular}

DNPM=National Department of Mineral Production. RADAM=Radar in the Amazon. CPRM=Brazilian Geological Survey. SUDAM=Superintendence for the Amazon Development. GEOMITEC=Geologia e Mineração, Trabalhos Técnicos Ltda. Reports are available at: http://geosgb.cprm.gov.br/ (CPRM); https://biblioteca.ibge.gov.br/ (RADAM); and http://www.sudam.gov.br/ (SUDAM). 
nepheline are undersaturated, not present in Uatumã volcanism.

m) Plot the data on the two $\mathrm{K}_{2} \mathrm{O} \times \mathrm{CaO} / \mathrm{K}_{2} \mathrm{O}$ diagrams, one designed for oversaturated (acid) and the other for saturated (intermediate) rocks.

\section{GEOLOGICAL CONTEXT}

The Amazon Craton is the largest craton of South America (Fig. 1) with $5,200,000 \mathrm{~km}^{2}$ (Santos 2003). To the west, southwest and northwest the craton is limited by the Phanerozoic Andean Belt. To the east and southeast the craton is bordered by collisional belts of the Brasilian Orogen (dominantly Ediacaran). The Amazon Craton is partially covered by extensive Phanerozoic basins, particularly in the west. The craton is organized in seven main provinces (Santos 2003) where Carajás is Archean, Sunsás is Mesoproterozoic, and five (Rio Negro, RondôniaJuruena, Tapajós-Parima, Trans-Amazon, and Central Amazon) are Paleoproterozoic (Fig. 1).
The Uatumã calc-alkaline volcanism was generated during the Orosirian as the most extensive volcanic tract in South America. Successive Andean-type magmatic arcs are present within the Tapajós-Parima Province (2030-1880 Ma; Santos et al. 2004) covering part of northern Brazil (Amazonas, Pará and Roraima States), southeastern Venezuela (Cuchivero Group and Caicara Formation; Rios 1972), SW Guyana (Burro-Burro and Kuyuwini Groups, Berrangé 1977), and West Suriname (Dalbana Formation; Bosma et al. 1983). The sampled volcanic rocks correspond to three formations: Surumu (NE Roraima State of Brazil, SE Venezuela, W Guyana), Iricoumé (SE Roraima, NW Pará, NE Amazonas states of Brazil), and Iriri (SE Amazon and west Pará states) formed at 19851860 Ma (Fig. 1). Two units previously included in the Uatumã magmatism (Ramgrab \& Santos 1974, Santos 1984) are not part of this study. The Sobreiro Formation of Carajás Province is older (Rhyacian to Siderian; Vasquez \& Costa 2008) and the Colider Group (Tarelow Neto et al. 2017) from the Rondônia-Juruena Province is younger,

Table II. Major elements of Uatumã volcanic rocks.

\begin{tabular}{|c|c|c|c|c|c|c|c|c|c|c|c|c|c|c|c|}
\hline & group & $\mathbf{n}$ & $\mathrm{SiO}_{2}$ & $\mathrm{Al}_{2} \mathrm{O}_{3}$ & $\mathrm{Fe}_{2} \mathrm{O}_{3}$ & FeO & MnO & MgO & $\mathrm{CaO}$ & $\mathrm{Na}_{2} \mathrm{O}$ & $\mathrm{K}_{2} \mathrm{O}$ & $\mathrm{TiO}_{2}$ & $\mathrm{P}_{2} \mathrm{O}_{5}$ & $\mathrm{H}_{2} \mathrm{O}$ & Total \\
\hline \multirow{5}{*}{ 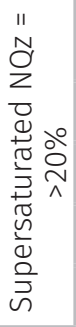 } & & 4 & 80.35 & 11.40 & 1.44 & 0.86 & 0.07 & 0.22 & 0.28 & 1.23 & 3.33 & 0.18 & a. & า.a. & 9.36 \\
\hline & AF rhyolite & 15 & 72.84 & 13.21 & 1.26 & 82 & 0.09 & 0.33 & 19 & 3.26 & 5.72 & 0.53 & 0.07 & 0.13 & 9.45 \\
\hline & Rhyolite & 34 & 72.34 & 13.25 & 1.77 & 1.03 & 0.09 & 0.35 & 0.89 & 3.96 & 4.89 & 0.27 & 0.15 & 0.24 & 9.23 \\
\hline & Rhyodacite & 43 & 68.88 & 15.71 & 2.17 & 1.14 & 0.09 & 0.77 & 1.89 & 3.88 & 3.88 & 0.41 & 0.22 & 0.11 & 99.15 \\
\hline & Dacite & 27 & 66.65 & 16.12 & 2.92 & 1.61 & 0.10 & 1.48 & 3.33 & 3.65 & 2.75 & 0.50 & 0.12 & 0.10 & 9.33 \\
\hline \multirow{3}{*}{ 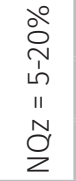 } & Quartz AF trachyte & 6 & 68.16 & 14.52 & 1.22 & 2.17 & 0.11 & 0.65 & 0.90 & 3.84 & 6.66 & 0.55 & 0.21 & 0.15 & 99.14 \\
\hline & Quartz trachyte & 11 & 67.51 & 15.32 & 1.32 & 3.08 & 0.17 & 0.79 & 1.58 & 4.10 & 5.28 & 0.47 & 0.11 & 0.13 & 99.86 \\
\hline & Quart latite & 14 & 65.05 & 15.44 & 2.28 & 2.32 & 0.13 & 1.58 & 3.11 & 4.12 & 3.75 & 0.44 & 0.23 & 0.24 & 98.69 \\
\hline \multirow{4}{*}{ 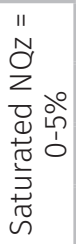 } & AF trachyte & 8 & 65.97 & 14.46 & 0.77 & 2.84 & 0.18 & 1.11 & 1.66 & 4.75 & 6.40 & 0.63 & 0.13 & 0.14 & 99.04 \\
\hline & Trachyte & 17 & 63.01 & 15.89 & 1.10 & 3.86 & 0.17 & 2.35 & 2.83 & 3.76 & 4.92 & 0.43 & 0.19 & 0.28 & 98.79 \\
\hline & Latite & 19 & 59.32 & 16.20 & 4.59 & 3.08 & 0.17 & 2.87 & 4.28 & 3.64 & 3.87 & 0.78 & 0.24 & 0.28 & 99.32 \\
\hline & Andesite & 21 & 55.13 & 16.80 & 3.63 & 5.35 & 0.19 & 4.22 & 6.11 & 3.73 & 2.19 & 0.44 & 0.21 & 0.15 & 98.15 \\
\hline
\end{tabular}

$\mathrm{n}=$ number of analysis; AF=Alkali Feldspar; $n . a .=$ not analysed. 
Statherian, 1760-1780 Ma (Barros et al. 2009) than Uatumã.

\section{RESULTS}

\section{The degree of silica saturation}

The fundamental classification concept is the determination of the amount of free silica or feldspathoid in the rock. To circumvent the difficulty and cost of determining quartz (eventually tridymite or chalcedony), we choose the effectiveness of using normative quartz (Nqtz) in place of modal quartz (Mqtz). We compared both attributes from classical type localities of volcanic rocks and of plutonic rocks (Fig. 2 and Table III). The chemical and modal compositions of the rocks are from Tröger (1935) whereas the normative compositions are here calculated from the chemical data of Tröger (1935).
Figure 2 displays positive correlation between modal and normative quartz allowing the use of normative values of quartz to determine the degree of silica saturation of volcanic rocks. Following Shand (1913) and Rittmann (1952), rocks are oversaturated that have excess of $\mathrm{SiO}_{2}$ over the other oxides, generating either silica minerals in the mode or quartz in the norm. Saturated volcanic rocks are neither oversaturated nor undersaturated with respect to silica, i.e., they have small amounts of either silica minerals or feldspathoids in the mode or norm. Undersaturated rocks with respect to silica, i.e. lack quartz and have feldspathoid (foid) or Mg-olivine in the mode or norm. The fundamental concept of silica saturation and the understanding of the subdivision of acid, intermediate, basic, and ultrabasic rocks was misinterpreted by the IUGS (International Union for Geological Sciences) who supported the use

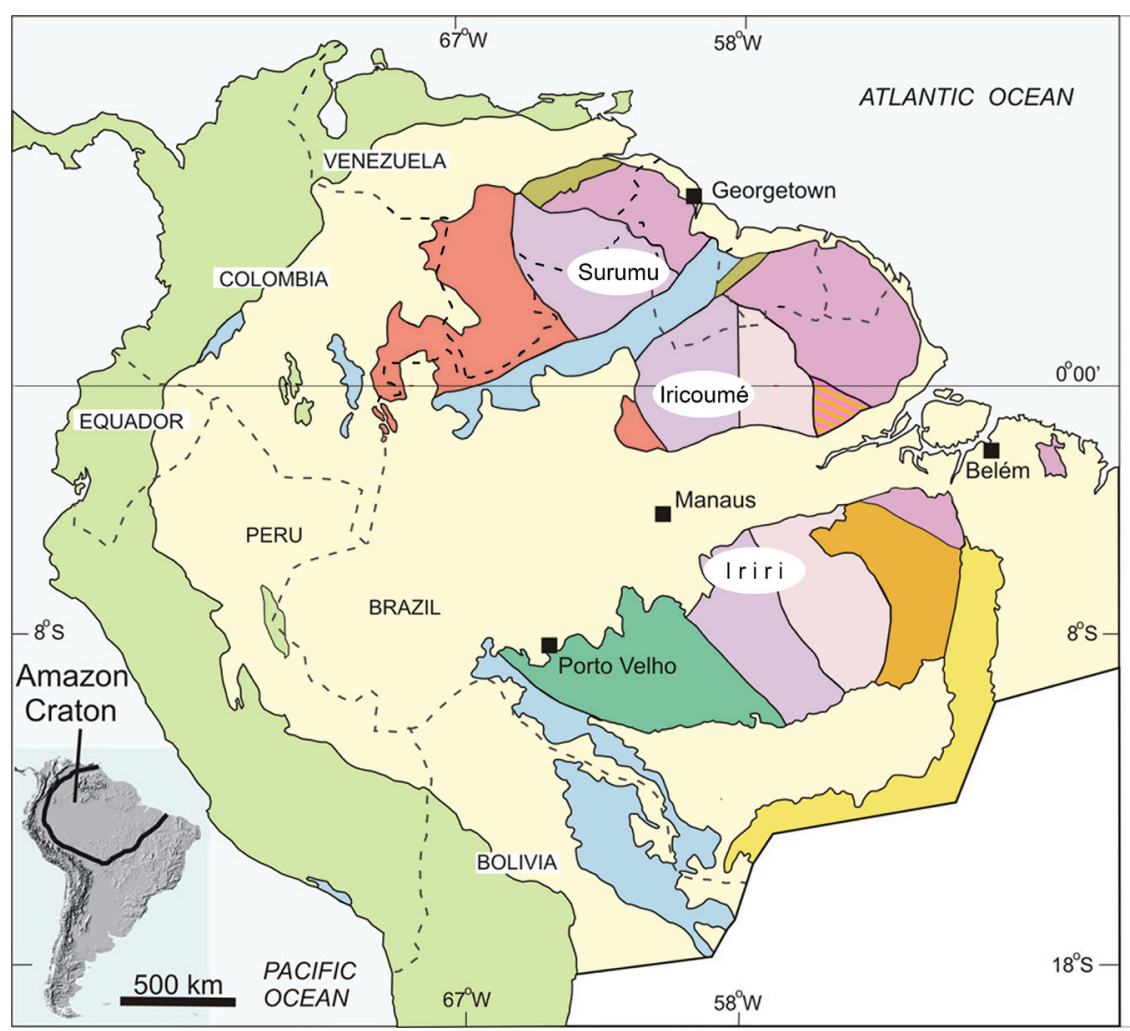

\section{TECTONIC UNITS}

Adapted from Santos (2003)

Phanerozoic basins

Andes Orogenic Belt

Paraguai-Araguaia Belt

K'Mudku- Sunsás, 1.45-1.10 Ga

Rondônia-Juruena, 1.82-1.54 Ga

Rio Negro, 1.82-1.52 Ga

Tapajós-Parima, 2.03-1.88 Ga

Transamazon, 2.26-2.01 Ga

Carajás, imbrication of Archean and Transamazonian belts

Carajás, 3.0-2.5 Ga

Central Amazon, Archean?

Calc-Alkaline volcanic rocks:

Surumu, 1974-1985 Ma

Iricoumé, 1875-1896 Ma

Iriri, 1870-1898 Ma

Figure 1. The Amazon Craton in Northern South America subdivided into provinces (Santos 2003). Volcanic rocks of this study are from the Tapajós-Parima Province (2030-1880 Ma) - Surumu, Iricoumé, and Iriri Groups. 
of the TAS diagram. Le Bas et al. (1986) and Le Maitre et al. (2002), based on Cox et al. (1979), assumed that the degree of silica saturation is determined by the content of $\mathrm{SiO}_{2}$ of the rock. But the controls are different. The book "Igneous Rocks" by Le Maitre et al. (2002) empirically defined (pages 49, 52, and 93) that an acid rock has more than 63 wt.\% $\mathrm{SiO}_{2}$; an intermediate rock has between $52 \%$ and $63 \% \mathrm{SiO}_{2}$, a basic rock has less than $52 \% \mathrm{SiO}_{2}$ and more than $45 \% \mathrm{SiO}_{2}$, and finally, an ultrabasic rock has $<45 \% \mathrm{SiO}_{2}$. However, the names acid, intermediate, basic, and ultrabasic, by definition (Shand 1913), are related to the degree of $\mathrm{SiO}_{2}$ saturation and not to the $\mathrm{SiO}_{2}$ content.

Some examples of misclassification using the content of $\mathrm{SiO}_{2}$ to separate the four major groups of rocks are the following:

- Olivine-rich basalts, composed by olivine (29.5-42.7\% $\left.\mathrm{SiO}_{2}\right)$, clinopyroxene (48\% $\left.\mathrm{SiO}_{2}\right)$, and bytownite $\left(48 \% \mathrm{SiO}_{2}\right)$ may have $\mathrm{SiO}_{2}<45 \%$ (see alkalic olivine basalt from Hawaii, sample C168 of MacDonald 1968). They are basic, not ultrabasic rocks.

- Lherzolites may have more than 45 wt.\% SiO2 (McDonough \& Rudnick 1998; Table
1, p. 145) and they are not basic, but ultrabasic rocks.

- Peridotites may have more $\mathrm{SiO}_{2}$ than $45 \%$ (McDonough \& Rudnick 1998; their Table 9, page 155), and are ultrabasic, not basic rocks.

- Basalts may have more than 52\% $\mathrm{SiO}_{2}$ and they are not intermediate rocks, but basic. See samples 11, 21, 40, 41, and 42 of Jensen (1976), Tables 1-2, pages 18-19.

- Trachyandesites, which are intermediate rocks, may have less than $45 \%$ silica and they are not ultrabasic rocks. See sample C183 from MacDonald (1968), Table 5, page 496.

- Hawaiites, which are alkalic andesites, are intermediate rocks, and have average of $47.9 \% \mathrm{SiO}_{2}$ (MacDonald, 1968, Table 8 , page 502; Nekvasil et al. 2004, Table 1). Using the TAS diagram hawaiite would be basic, not intermediate rock.

- Trachytes are formed by alkali feldspar (65-67 wt.\% $\mathrm{SiO}_{2}$ ) and commonly have more than 63 wt.\% $\mathrm{SiO}_{2}$ (e.g. Sial et al. 1987, Renzului et al. 2002, Nekvasil et al. 2004, Hagos et al. 2010, Martel et al. 2013). Also,

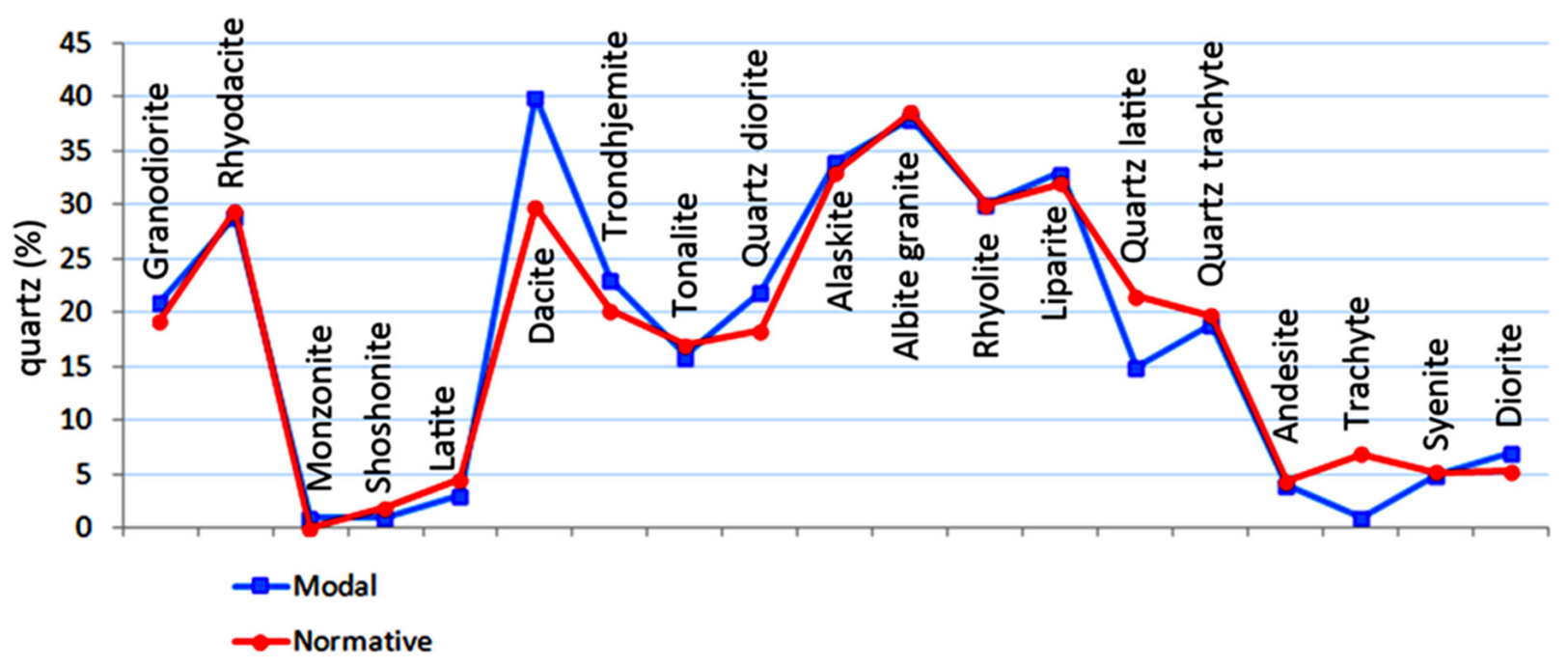

Figure 2. Modal and normative amount (vol.\%) of quartz in rocks from type localities. Chemical and modal compositions from Tröger (1935). Normative compositions as calculated in this work. 
the upper limit of $\mathrm{SiO}_{2}$ for intermediate rocks of Cox et al. (1979) in the TAS diagram is high (69wt.\%) representing the presence of quartz (modal and normative) above 5 vol.\%, therefore quartz trachytes, which are not intermediate, but acid rocks. This positions most trachytes as acid rocks instead of intermediate rocks.

- Clinopyroxenite, websterite, and particularly orthopyroxenite have $>45$ wt.\% $\mathrm{SiO}_{2}$ (e.g,. Mukasa \& Shervais 1999,
Maalфe 2005) and may have $>52 \% \mathrm{SiO}_{2}$ (e.g. Ahmadipour et al. 2003, Anbarasu et al. 2011, Maier et al. 2015). However, they are neither intermediate nor basic rocks, but ultrabasic.

- Hornblendites, composed by $>90$ vol.\% hornblende (hornblende has 51 wt.\% $\mathrm{SiO}_{2}$ ) may have $>45$ wt.\% $\mathrm{SiO}_{2}$ (e.g. Holub, 2004, Mendes et al. 2004) and they are not basic rocks, but ultrabasic.

Table III. Comparison of Modal and Normative quartz of magmatic rocks from type localities.

\begin{tabular}{|c|c|c|c|}
\hline Rock & Type locality & Mqtz \% & Nqtz \% \\
\hline Alaskite & South Alaska, USA & 34 & 33.08 \\
\hline Albite-granite & Lapland, Sweden & 38 & 38.61 \\
\hline Diorite & West Finland & 7 & 5.31 \\
\hline Farsundite & South Norway & 25 & 30.74 \\
\hline Granodiorite & NW Sacramento, California & 21 & 19.3 \\
\hline Monzonite & South Tirol, Germany & 1 & 0.00 \\
\hline Opdalite & Trondhjeim, Norway & 16 & 12.86 \\
\hline Quartz diorite & Yellowstone, USA & 22 & 18.28 \\
\hline Syenite & Dresden, Germany & 5 & 5.19 \\
\hline Tonalite & South Tirol, Germany & 16 & 17.03 \\
\hline Trondhjemite & Trondhjeim, Norway & 23 & 20.15 \\
\hline Andesite & Catamarca, Argentina & 4 & 4.31 \\
\hline Basalt & Dresden, Germany & 0 & 2.41 \\
\hline Basanite & Bohemian Mountains, Czech Republic & 0 & 0.00 \\
\hline Dacite & Romenia & 40 & 29.82 \\
\hline Dellenite & Halsingland, Sweden & glassy & 23.58 \\
\hline Latite & SW Rome, Italy & 3 & 4.48 \\
\hline Liparite & Lipari Island, Italy & 33 & 32.02 \\
\hline Phonolite & Bohemian Mountains, Czech Republic & 0 & 0.00 \\
\hline Quartz latite & SW Nevada, USA & 15 & 21.47 \\
\hline Quartz trachyte & SW Colorado, USA & 19 & 19.76 \\
\hline Rhyodacite & Marysville, Australia & 29 & 29.41 \\
\hline Rhyolite & North Flagstaff, Arizona, USA & 30 & 30.00 \\
\hline Shoshonite & Yellowstone, USA & 1 & 1.82 \\
\hline Trachyte & SE of Bonn, Germany & 1 & 6.87 \\
\hline
\end{tabular}

Modal quartz (Mqtz) from Tröger (1935). Normative quartz (Nqtz) from this work. 
The degree of silica saturation depends on the mineralogical composition of the rock. Some rock forming minerals contain higher and others lower $\mathrm{SiO}_{2}$ (Table IV). From this table, for example, an ultrabasic rock composed by dominant orthopyroxene (52-60\% wt. $\mathrm{SiO}_{2}$ ) will have $>52 \%$ $\mathrm{SiO}_{2}$ and would be erroneously classified as an intermediate rock using the TAS diagram.

\section{The separation of ultrabasic and basic rocks}

The limit between ultrabasic and basic rocks was placed at 45 wt.\% $\mathrm{SiO}_{2}$ (Le Bas et al. 1986). However, $\mathrm{SiO}_{2}$ is not a discriminant oxide because there are basic rocks with less than $45 \% \mathrm{SiO}_{2}$ (MacDonald 1968) and ultrabasic rocks with more than $45 \% \mathrm{SiO}_{2}$ (McDonough \& Rudnick 1998). Pyroxene-rich rocks such as Iherzolite, harzburgite, wehrlite, and websterite have dominantly $\mathrm{SiO}_{2}$ content $>45 \mathrm{wt} . \%$. This is

Table IV. $\mathrm{SiO}_{2}$ content of rock-forming minerals.

\begin{tabular}{|c|c|}
\hline Mineral & Sio $_{\mathbf{2}} \%$ (\%) \\
\hline Olivine (fayalite) & 29.50 \\
\hline Olivine (forsterite) & 42.70 \\
\hline Plagioclase (anorthite) & 44.40 \\
\hline Amphibole (Fe-hornblende) & 44.50 \\
\hline Clinopyroxene (augite) & 48.00 \\
\hline Amphibole (Mg-hornblende) & 51.00 \\
\hline Orthopyroxene (hypersthene) & 52.00 \\
\hline Plagioclase (labradorite) & 53.00 \\
\hline Clinopyroxene (pigeonite) & 54.70 \\
\hline Clinopyroxene (diopside) & 55.50 \\
\hline Plagioclase (andesine) & 58.00 \\
\hline Orthopyroxene (enstatite) & 60.00 \\
\hline Plagioclase (oligoclase) & 63.50 \\
\hline Alkali feldspar (orthoclase) & 65.00 \\
\hline Alkali feldspar (albite) & 67.00 \\
\hline Alkali feldspar (anorthoclase) & 67.70 \\
\hline IMA (Internatona Mineralogica & \\
\hline
\end{tabular}

Source: IMA (International Mineralogical Association). https://www.ima-mineralogy.org. because pyroxenes (clino- and ortho-) have 5460 wt.\% $\mathrm{SiO}_{2}$ (Table IV).

Is the mantle formed by basic or ultrabasic rocks? Seven models for mantle composition have more than $45 \%$ silica (Table $\mathrm{V}$ ). According to the $45 \% \mathrm{SiO}_{2}$ upper limit for ultrabasic rocks (Cox et al. 1979, Le Bas et al. 1986) Earth's mantle would be composed by basic rocks.

This is sufficient reason to abandon the use of silica content alone to separate ultrabasic from basic rocks. $\mathrm{Al}, \mathrm{Ca}$, and $\mathrm{Mg}$ are more important major elements than Si to separate basic and ultrabasic rocks. Ultrabasic rocks are characterized by absence of free $\mathrm{SiO}_{2}$ (Mqtz or Nqtz), high MgO content (>20\%), plus low amounts of plagioclase (up to 10 vol.\%), $\mathrm{Al}_{2} \mathrm{O}_{3}$ $(<12 \%)$, and $\mathrm{CaO}(<12 \%)$. Most ultrabasic rocks are coarse grained and classified according to their mineralogical composition (modal classification). Fine-grained ultrabasic lavas are present in Archean (e.g. Sun \& Nesbit 1978) and Paleoproterozoic (Nalivkina 2012, Park 2015) greenstone belts. A chemical approach may be necessary to separate these lavas from basalts considering that ultrabasic rocks have less calcium and aluminium, and more magnesium than basalts. Jensen's (1976) Fe-Ti/Al/Mg cation diagram is useful in spite of lack of calcium.

\section{The classification of Irvine \& Baragar (1971)}

Some chemical approaches were proposed in the past to classify volcanic rocks where the possible best example is the system of Irvine \& Baragar (1971) based on the normative composition (CIPW) and normative colour index of rocks. However, the normative compositionbased classifications failed because they are uncapable to perform an accurate distribution of the normative Ab between alkali feldspar and plagioclase. Albite (modal) is alkali feldspar commonly present in many felsic volcanic rocks as individual grains or as perthite intergrowths 
Table V. $\mathrm{SiO}_{2}$ content of Earth's mantle.

\begin{tabular}{|c|c|c|c|c|c|c|c|}
\hline Model & CI Chondrite & CI LOSIMAG & PYROLITE & PRIMA & & $\begin{array}{c}\text { Cl Carb } \\
\text { Chondrite }\end{array}$ & PYROLITE \\
\hline Source & $\begin{array}{c}\text { Hart \& } \\
\text { Zindler 1986) }\end{array}$ & $\begin{array}{c}\text { Hart \& } \\
\text { Zindler } \\
(1986)\end{array}$ & $\begin{array}{c}\text { MCDonough \& } \\
\text { Sun (1995) }\end{array}$ & $\begin{array}{c}\text { Allègre et } \\
\text { al. (1995) }\end{array}$ & $\begin{array}{c}\text { Jagoutz et } \\
\text { al. } \\
(1979)\end{array}$ & $\begin{array}{c}\text { Taylor \& } \\
\text { McLennan } \\
\text { (1985) }\end{array}$ & $\begin{array}{c}\text { Ringwood } \\
\text { (1979) }\end{array}$ \\
\hline $\mathrm{SiO}_{2}$ & 49.52 & 45.96 & 45.00 & 46.52 & 45.15 & 49.9 & 45.1 \\
\hline
\end{tabular}

in K-feldspar (orthoclase, sanidine, rarely microcline). Albite also occurs as solid solution with sanidine in high- temperature alkalic volcanic rocks forming anorthoclase (Deer et al. 2013), which is dominated by albite (Na 64-90\%) molecules over sanidine ( $\mathrm{K} 10-36 \%$; Deer et al. 2013). This feldspar is confined to volcanic, not plutonic rocks (Gill 2010) being more common in trachytes, alkali trachytes (e.g. Johnson et al. 1989, Gill 2010), and alkali rhyolites (e.g. Coats et al. 1968). Alkali feldspar trachyte with anorthoclase may have up to 10 vol.\% Na-plagioclase (albite, oligoclase) and anorthoclase-bearing trachyte may have up to $30 \% \mathrm{Na}$-plagioclase. How to distribute the amount of $\mathrm{Na}_{2} \mathrm{O}$ from the chemical analysis between plagioclase and anorthoclase? The diagram of Irvine \& Baragar (1971, their Figure 11) allocated all $\mathrm{Na}_{2} \mathrm{O}$ (normative albite) to plagioclase lowering the actual NCP-Normative Composition of Plagioclase. These attributes show that the amount of analysed $\mathrm{Na}_{2} \mathrm{O}$ of a volcanic rock may be originated either from plagioclase or from alkali feldspar. Because $\mathrm{Na}_{2} \mathrm{O}$ is present in two different and alternative minerals used for rock classification (plagioclase and alkali feldspar), the $\mathrm{Na}_{2} \mathrm{O}$ content and the modal and normative albite generate questionable results when used in classificatory diagrams. The common procedure of summing up $A b$ and $A n$ in normative analyses to establish the value of $\mathrm{P}$ (plagioclase) produces imprecise results by exaggerating total $P$ (see Irvine \& Baragar 1971, Fig. 7, p. 538).

Irvine \& Baragar (1971) adequately classify rocks with remarkably high or low feldspar ratios $(P / K)$. Plagioclase-rich rocks (andesites and basalts) and alkali feldspar-rich rocks (rhyolites [stricto sensu] and trachytes) are adequately classified. However, the majority of common volcanic rocks (those between plagioclase-rich and alkali feldspar-rich rocks) may have albite distributed in the two feldspars (plagioclase and K-feldspar). Rhyolite may be misclassified as dacite whereas latite may be misclassified as andesite (see Fig. 7 of Irvine \& Baragar 1971). The $\mathrm{NCl} \times$ NCP diagrams only classify 5 (plus 1 subfamily, icelandite) of the 16 families of common volcanic rocks, see Fig. 3 (for rhyolite, dacite, andesite, and basalt) and Fig. 11 of Irvine \& Baragar (1971) for trachyte.

The $\mathrm{NCl} \times \mathrm{NCP}$ diagram is useful to discriminate basalt and andesite. The $\mathrm{NCl} x$ NCP diagram passed in the test made with andesites. Andesites from the type-locality and andesite averages plot within the field of andesite. Another test using quartz basalt and quartz andesite from the Eastern Carpathians in Romenia (data from Jurje et al. 2014) separates the two groups of rocks (Fig. 3). 


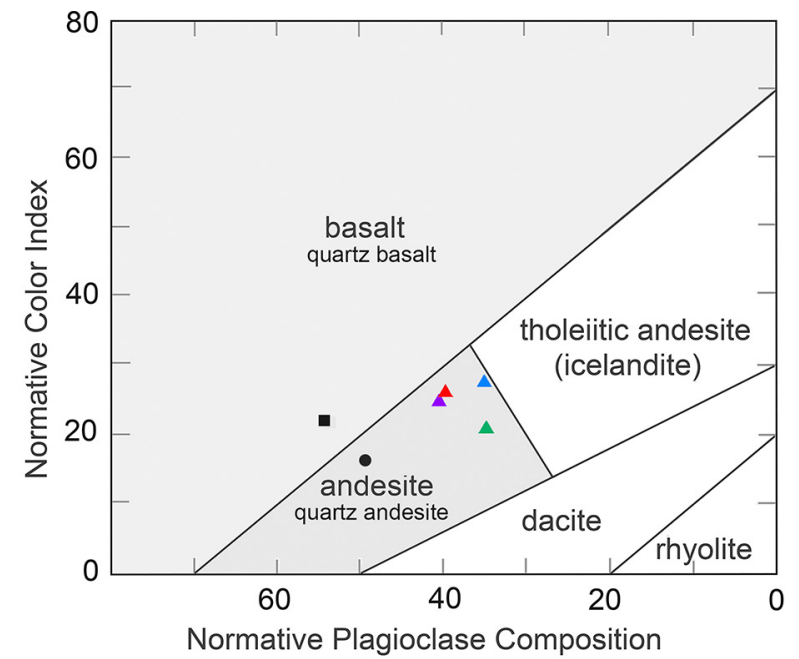

Figure 3. Reproduction of Figure 7 of Irvine \& Baragar (1971), recommended for separation of basalt + quartz basalt from andesite + quartz andesite based on the normative plagioclase composition and normative colour index. Also, useful to identify tholeiitic andesites (icelandites), which have lower NPC and higher NCl compared to calc-alkaline andesites. Triangles symbology: red, Uatumã andesites (Santos 2012); purple, andesite typelocality, La Hoyada, Catamarca, Argentina (Becke 1899, from Tröger 1935); blue, andesite world average ( $n=49$; Nockolds 1954), and green, andesite world average ( $n=2600$; Le Maitre 1976); $\bullet$ = average of five quartz andesites from Eastern Carpathians, Romenia; $\boldsymbol{\square}$ = average of $\mathbf{2 0}$ quartz basalts (data from Jurje et al. 2014); NPC=[100An/(An+Ab+5/3Ne)]; $\mathrm{NCl}=d i+h e m+h y+i l m+$ mag + ol.

\section{Reinstating the names quartz andesite and quartz basalt}

Our classification keeps the names quartz andesite and quartz basalt (see Fig. 4), which are rocks moderately oversaturated in SiO2, with 5-20\% Nqtz and less than 10\% alkali feldspar. Separation between quartz andesite and quart basalt is made using $\mathrm{NCl}$ (Normative Colour Index) and NPC (normative plagioclase composition) indexes. Rocks with NPC $<50 \%$ (normative andesine) are quartz andesites and rocks with NPC $>50 \%$ (normative labradorite or bytownite) are quartz basalts, following the Irvine \& Baragar (1971) proposition to discriminate andesite and basalt (Fig. 3). This disagrees with the TAS classification where these names are omitted and included as basalt and andesite. The TAS diagram (Fig. 2.11, p. 31 of Le Maitre et al. 2002) even extended the field of basalt and andesite to $20 \%$ quartz. The result is that basalt (a basic rock by definition) and andesite (an intermediate rock by definition) may be acid rocks with up to $20 \%$ quartz. So, according to IUGS, basalt is no longer an exclusively basic rock, but includes acid rocks. We reaffirm the use of quartz andesite and quartz basalt as used by researchers such as Turner (1895), Bartrum (1937), Bowen (1954), Rittmann (1952, 1973), Negendank (1973), Allen (1986), Zhigang (1990), Potts \& West (2000), Berbeleac et al. (2004), Huang et al. (2012), Santos (2012), and Jurje et al. (2014). The names of basalt and andesite are restricted here for rocks with up to $5 \%$ Mqtz or $5 \%$ Nqtz following worldwide pre-TAS understanding.

\section{Testing the TAS diagram}

There are 16 major families of volcanic rocks that are neither ultrabasic nor feldspathoid-bearing: basalt, quartz basalt, andesite, quartz andesite, trachyandesite, quartz trachyandesite, latite, quartz latite, trachyte, quartz trachyte, alkali feldspar quartz trachyte, alkali feldspar trachyte, dacite, rhyodacite, rhyolite, and alkali feldspar rhyolite. These are shown in QAP (Quartz-Alkali feldspar-Plagioclase) diagram of Fig. 4 (adapted from Streckeisen 1978). Here the volcanic equivalent for the plutonic rocks of 60-90 vol.\% quartz (quartz-rich granitoid) has a suggested name of "quartz-rich rhyolitoid" (Field 1 of Fig. 4).

The alkali versus silica diagram was not designed to classify rocks, but to discriminate between either alkaline or tholeiitic suites of volcanic rocks (MacDonald \& Katsura 1964, Fig. 1, p. 87; MacDonald 1968, Fig. 7, p. 514) or alkaline and subalkaline rocks (Irvine \& Baragar 1971; Fig. 3 , p. 532). A single diagram using $\mathrm{K}, \mathrm{Na}$, and $\mathrm{Si}$ is unable to classify common magmatic rocks 


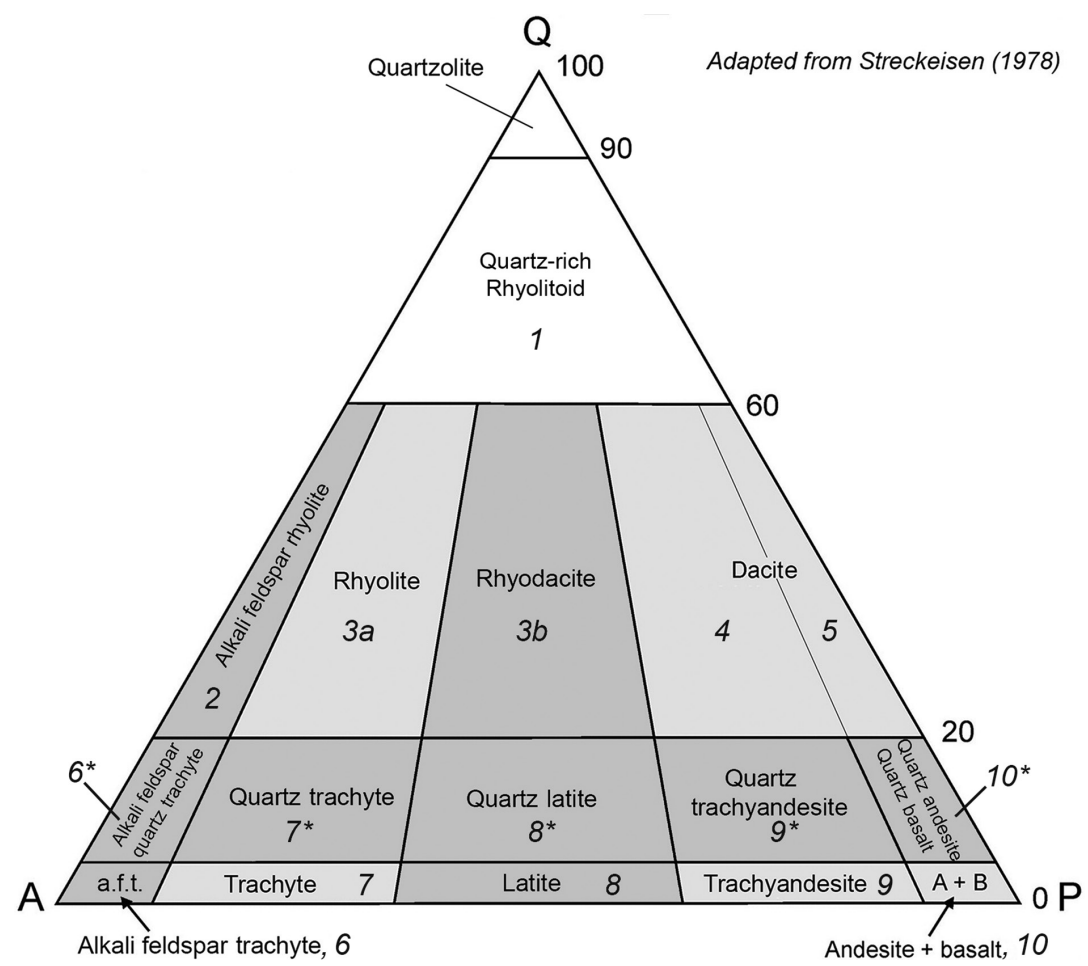

Figure 4. Q (Quartz) - A (Alkali feldspar) - $P$ (Plagioclase) diagram adapted from Streckeisen (1978) with 16 major families of common volcanic rocks. The TAS diagram is able to classify six of them (light grey) and unable to classify 10 of them (dark grey). Name of quartzrich rhyolitoid (1) is here introduced in analogy of quartz-rich granitoid for plutonic rocks (Streckeisen 1976).

because one mandatory element is missing, and this is calcium. The TAS diagram was tested by plotting rock data from the Amazon Craton, from classic world average compositions (Nockolds 1954 and Le Maitre 1976) and from type-localities (Tröger 1935) - Fig. 5.

The original TAS diagram of Cox et al. (1979), modified by Le Bas et al. (1986) is able to classify 6 of the existing 16 families of common volcanic rocks. The main problem is that the ten missing families are misclassified among the other six families. The following is a list of the main misclassifications:

- All latites are misclassified as andesite, trachyandesite, or as basaltic trachyandesite.

- Most of andesites plot outside the field "andesite". They are misclassified as basaltic trachyandesite, trachyandesite, and basaltic andesite.

- All quartz latites are misclassified as dacite or trachyte.
- All quartz trachytes are misclassified as trachyte.

- Some trachytes are misclassified as trachyandesite.

- All rhyodacites (arguably the most common felsic volcanic rock on Earth) are misclassified as rhyolite and dacite.

- All dellenites are misclassified as rhyolite.

- Alkali feldspar trachytes are misclassified as trachyte and rhyolite.

- Alkali feldspar rhyolite is misclassified as rhyolite.

The classification of magmatic rocks should maintain the worldwide- accepted correlation between the names of plutonic and volcanic rocks that have similar chemical and modal compositions. For example, the volcanic equivalent of diorite is andesite; latite corresponds to monzonite. This equivalency is lost in the TAS misclassification because most volcanic names loose their correlation with plutonic equivalents. Examples in the TAS diagram: 
- The plutonic correspondent of monzonite is andesite (instead of latite).

- The volcanic correspondent of monzogranite is dacite (instead of rhyodacite).

- The plutonic correspondent of quartz trachyte is granite (instead of quartz syenite).
- The volcanic equivalent of quartz monzonite is dacite (instead of quartz latite).

In sum, the Le Bas et al. (1986) - modified from Cox et al. (1979) - diagram generates (generic) classifications of volcanic rocks. This procedure is leading to the artificial extinction of several existing families, some of them among the most common felsic volcanic rocks on Earth such as rhyodacite and latite.

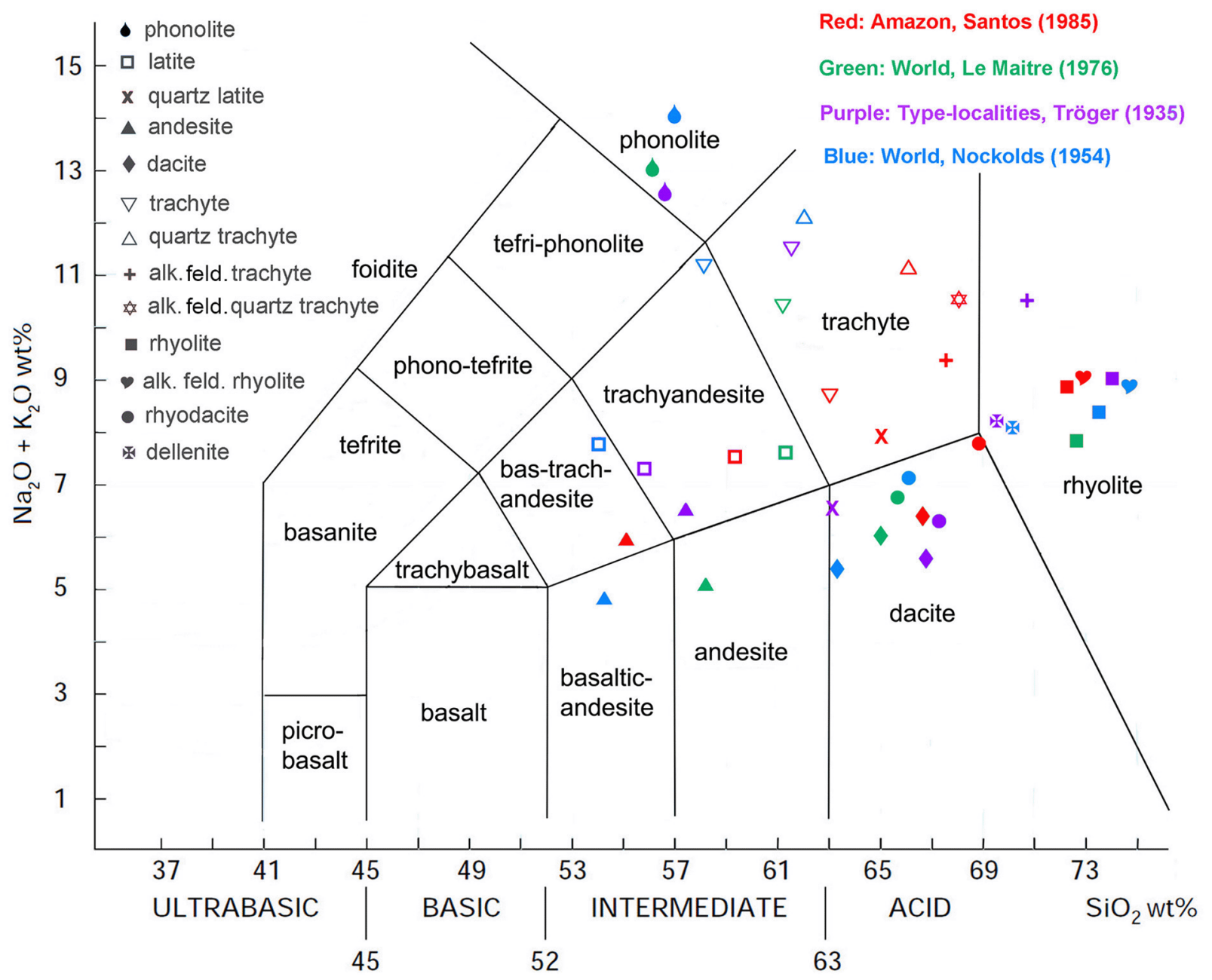

Figure 5. Test of TAS (Total Alkali-Silica) diagram (Le Maitre et al. 2002) to classify rocks from type localities (Tröger 1935), from the Amazon Craton (Santos 1985), and world average compositions (Nockolds 1954, Le Maitre 1976). Data are from Amazon (red), type-localities (purple) and world average compositions (green = Le Maitre 1976; blue $=$ Nockolds 1954). Symbols for rock names are in upper left corner. The result of this plot indicates several misclassifications as summarized in the text. The $\mathrm{SiO}_{2}$-based incorrect limits between ultrabasic-basic ( $45 \%$ ), basic-intermediate ( $52 \%)$, and intermediate-acid ( $63 \%$ ) rocks also shown. 


\section{The KCK Classification ( $\mathrm{CaO} / \mathrm{K}_{2} \mathrm{O}$ versus $\mathrm{K}_{2} \mathrm{O}$ )}

The KCK diagrams are simple, robust, and capable of classifying all 16 families of common volcanic rocks. The diagrams use the three major elements with the largest variation among volcanic rocks ( $\mathrm{Si}-\mathrm{K}-\mathrm{Ca}$ ), from less- to more- evolved types. Here we plot the $\mathrm{CaO} / \mathrm{K}_{2} \mathrm{O}$ ratio against the $\mathrm{K}_{2} \mathrm{O}$ content where $\mathrm{CaO}$ reflects the plagioclase content and $\mathrm{K}_{2} \mathrm{O}$ reflects the $\mathrm{K}$-feldspar content. Of the two diagrams, one is for saturated (intermediate) rocks and the other for oversaturated (acid) rocks. The diagrams display the compositions of 218 volcanic rocks from the Amazon Craton combined with compositions of other rocks from known localities, world averages, and type-localities. Compositions from type localities and world averages are used to test the proposed limits among types of rocks.

The proposed classification of volcanic rocks is based on two major parameters:

a) Degree of silica saturation (Shand 1913) - four groups are defined (limits of degrees of saturation are from Shand 1913, Rittmann 1952, Streckeisen 1976):

- Qtz $=0-5$ vol.\% (saturated rocks)
- Qtz $=5-20 \%$ (moderately oversaturated rocks)

- $\mathrm{Qtz}=20-60 \%$ (oversaturated rocks)

- Qtz $=0 \%$, either normative olivine or feldspathoid $=0-5 \%$ (undersaturated)

The undersaturated rocks are basicultrabasic and feldspathoid-bearing alkaline rocks; the saturated are named intermediate rocks and the oversaturated acid rocks following Shand (1947) and Yoder \& Tilley (1962). We reinforce that the degree of silica saturation is not measured by the $\mathrm{SiO}_{2}$ content of the rock but by the presence or absence of modal or normative quartz, feldspathoid, or olivine.

b) The feldspar ratio (proportion between plagioclase and alkali feldspar); five groups are recognized:

- Plagioclase-rich rocks (alkali feldspar is < 10 vol.\%): andesite, quartz andesite, dacite.

- Alkali feldspar-rich rocks (plagioclase is $<10 \%$ ): alkali feldspar rhyolite, quartz alkali feldspar trachyte and alkali feldspar trachyte.

- Rocks dominated by plagioclase (plagioclase $>2 / 3$ of feldspars): andesite,

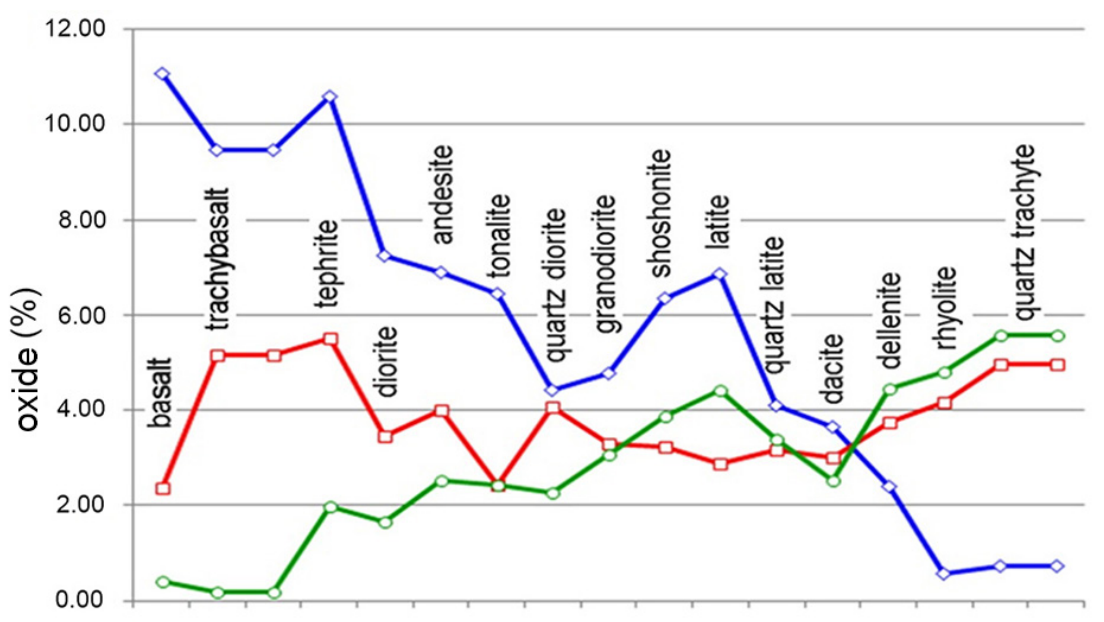

$\sim \mathrm{CaO}$ basalt / quartz trachyte ratio $=15.36$ $-\square-\mathrm{Na}_{2} \mathrm{O}$ basalt / quartz trachyte ratio $=2.08$ $\multimap \mathrm{K}_{2} \mathrm{O}$ basalt / quartz trachyte ratio $=13.59$
Figure 6. Distribution of $\mathrm{Na}_{2} \mathrm{O}, \mathrm{CaO}$, and $\mathrm{K}_{2} \mathrm{O}$ of magmatic rocks from less evolved on the left to more evolved on the right. Data from type-localities from Tröger (1935). 
quartz andesite, dacite, basalt, quartz basalt.

- Rocks dominated by alkali feldspar (alkali feldspar >2/3 of feldspars): rhyolite, quartz trachyte, and trachyte.
- Rocks with \pm equivalent content (plagioclase and alkali feldspar between 1/3 and 2/3): rhyodacite, quartz latite, latite.

Considering the chemical variations of $\mathrm{K}_{2} \mathrm{O}$, $\mathrm{CaO}$, and $\mathrm{Na}_{2} \mathrm{O}$ (Fig. 6) of 17 rock-types, from less

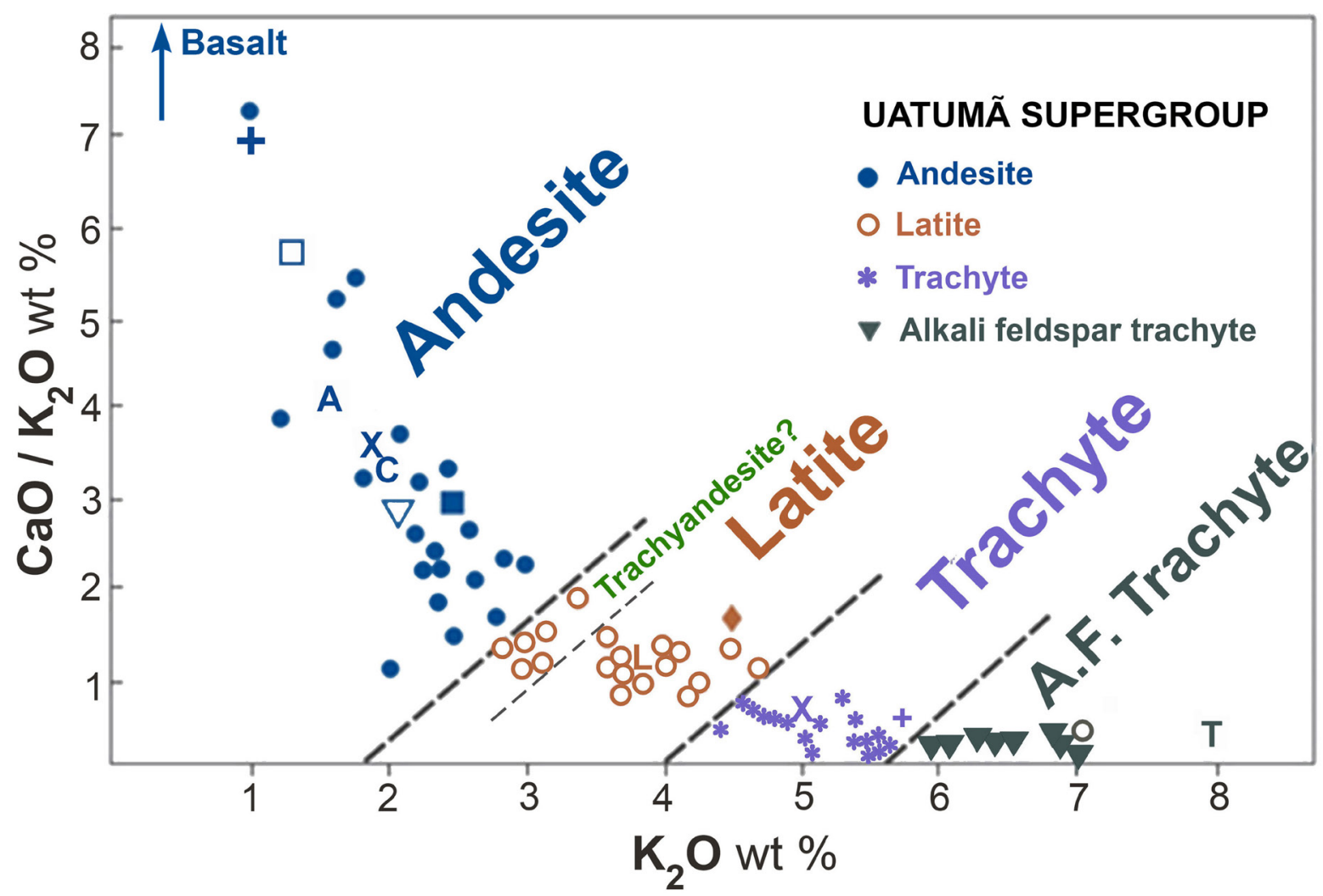

+ 15 andesites, Mount Pelée, Martinica, Roobol \& Schmit (1978)

A 2600 andesites, Le Maitre (1976)

X 10 andesites, Andes, Gunn et al. (1974)

C Andesites, Cascades, USA, Irvine \& Baragar (1971)

Andesites, Fidji, Jakes \& White (1972)

$\nabla$ Andesite world average, Daly (1933)

Andesite, type-locality, Catamarca, Argentina, Becke (1899)

Latite, type-locality, Italy, Washington (1906)

L 198 latites, Le Maitre (1976)

X 554 trachytes, Le Maitre (1976)

+ 48 trachytes, Daly (1933)

T Trachyte, Tröger (1935)

O Trachytes, Tristão da Cunha, Irvine \& Baragar (1971)

Figure 7. KCK diagram for intermediate rocks with distribution of Uatumã volcanic rocks (legend in upper right). Thirteen known rock compositions and world averages (listed below the graph) are used to test the diagram. 
evolved basalt to more evolved quartz trachyte (compositions from Tröger 1935) there are strong variations in the $\mathrm{K} 2 \mathrm{O}$ and $\mathrm{CaO}$ contents and little variation in $\mathrm{Na}_{2} \mathrm{O}$. Rhyolite has 11.75 times more $\mathrm{K}_{2} \mathrm{O}$ (average $=4.82 \%$ ) than basalt (average $=0.41 \%)$ and 19.75 times less $\mathrm{CaO}(0.56 \%)$ than basalt (11.06\%). The difference in the $\mathrm{Na}_{2} \mathrm{O}$ content of the end members basalt (2.38\%) and quartz trachyte $(4.18 \%)$ is $1.76 \%$. The $\mathrm{Na}_{2} \mathrm{O}$ content of andesite and rhyolite is similar, around $4 \%$. We observe that $\mathrm{Na}_{2} \mathrm{O}$ is not a discriminating oxide and therefore is not significant for the classification of volcanic rocks.

$\mathrm{CaO}$ and $\mathrm{K}_{2} \mathrm{O}$ have negative correlation. $\mathrm{CaO}$ contents decrease from less evolved to more evolved rocks, but $\mathrm{K}_{2} \mathrm{O}$ increases. $\mathrm{CaO}$ diminishes 15 times $(1,500 \%)$ from basalt to quartz trachyte whereas $\mathrm{K}_{2} \mathrm{O}$ increases more than 13 times $(1,300 \%)$. These two elements are adequate for a classification scheme. The $\mathrm{CaO} / \mathrm{K}_{2} \mathrm{O}$ ratio enhances the differences in the behaviour of the two elements and is the selected ratio for use against the $\mathrm{K}_{2} \mathrm{O}$ content, forming $\mathrm{KCK}$ diagrams.

The first diagram is dedicated to the intermediate volcanic rocks (alkali feldspar trachyte, trachyte, latite, andesite, trachyandesite, basalt), namely rocks with $<5 \%$ Nqtz. Undersaturated alkaline rocks carrying normative nepheline (0-5\%) are not included in the diagram, such as alkali feldspar trachyte, trachyte, latite, and andesite (all feldspathoid bearing). Sixty-five out of 218 analysed samples have $<5 \%$ Nqtz. These compositions were tested in the Irvine \& Baragar (1971) diagram (Fig. 4) to check for the presence of basaltic rocks. None was detected, in agreement with the absence of basalts in the Uatumã magmatism. The KCK diagram lacks a field for basalt because this rock type has high $\mathrm{CaO} / \mathrm{K}_{2} \mathrm{O}$ ratio and plots above the upper limit for andesite at about 8. The $\mathrm{CaO} / \mathrm{K}_{2} \mathrm{O}$ ratios of world average compositions of basalt are 12.71 (Nockolds 1954) and 22.9 (Le
Maitre 1976). Representative basalt of Tröger (1935) has $\mathrm{CaO} / \mathrm{K}_{2} \mathrm{O}=27$. Basalts are identified and separated from andesites using the Irvine \& Baragar (1971) NCI x NPC diagram (Fig. 4).

The distribution of sixty-five points in the KCK diagram for intermediate rocks follows a cubic parabolic curve from the richest $\mathrm{CaO}$ andesite to the alkali feldspar trachyte with higher $\mathrm{K}_{2} \mathrm{O}$ content. Five groups are separated according to their contents of $\mathrm{K}_{2} \mathrm{O}$ and $\mathrm{CaO} / \mathrm{K}_{2} \mathrm{O}$ = andesite, trachyandesite, latite, trachyte, and alkali feldspar trachyte.

Fig. 7 shows the presence of more latite and trachyte than considered before using classifications based on thin sections (SUDAMGEOMINERAÇÃO 1972, SUDAM-GEOMITEC 1972, Montalvão et al. 1975, Oliveira et al. 1975, Araújo et al. 1976, SUDAM-GEOMITEC 1976, Pessoa et al. 1977, Veiga Jr et al. 1979, Melo et al. 1978, Bizzinella et al. 1980).

About $40 \%$ of Uatumã rocks previously interpreted as andesite, are latite and also trachyandesite. Some andesites and high-K andesites (Gill 1981) have excess $\mathrm{K}_{2} \mathrm{O}$ (>3.5 wt.\%) and actually are latites. Other "andesites" have low CaO (low plagioclase) and are therefore trachyandesites.

After plotting the data of Uatumã volcanic rocks (Fig. 7), the diagram was tested using 13 known rock compositions from the literature. The data lack alkali feldspar trachytes because the sources were published prior to mid-1970. The name alkali feldspar trachyte was introduced in 1978 by Streckeisen. The alkali feldspar trachytes of Fig. 7 were originally classified as "trachytes". This field is presently subdivided into two, which are separated by the content of $\mathrm{K}_{2} \mathrm{O}$ at around 6 wt.\%. All trachytes have small amounts of $\mathrm{CaO}$ ( $<1$ wt.\%) and $\mathrm{K}_{2} \mathrm{O}$ from $4.2 \%$ to $8 \%$. Trachytes with higher $\mathrm{K}_{2} \mathrm{O}$ (from $6 \%$ to $8 \%$ ) and $\mathrm{CaO}<0.5 \%$ are from the alkali feldspar trachyte family. 


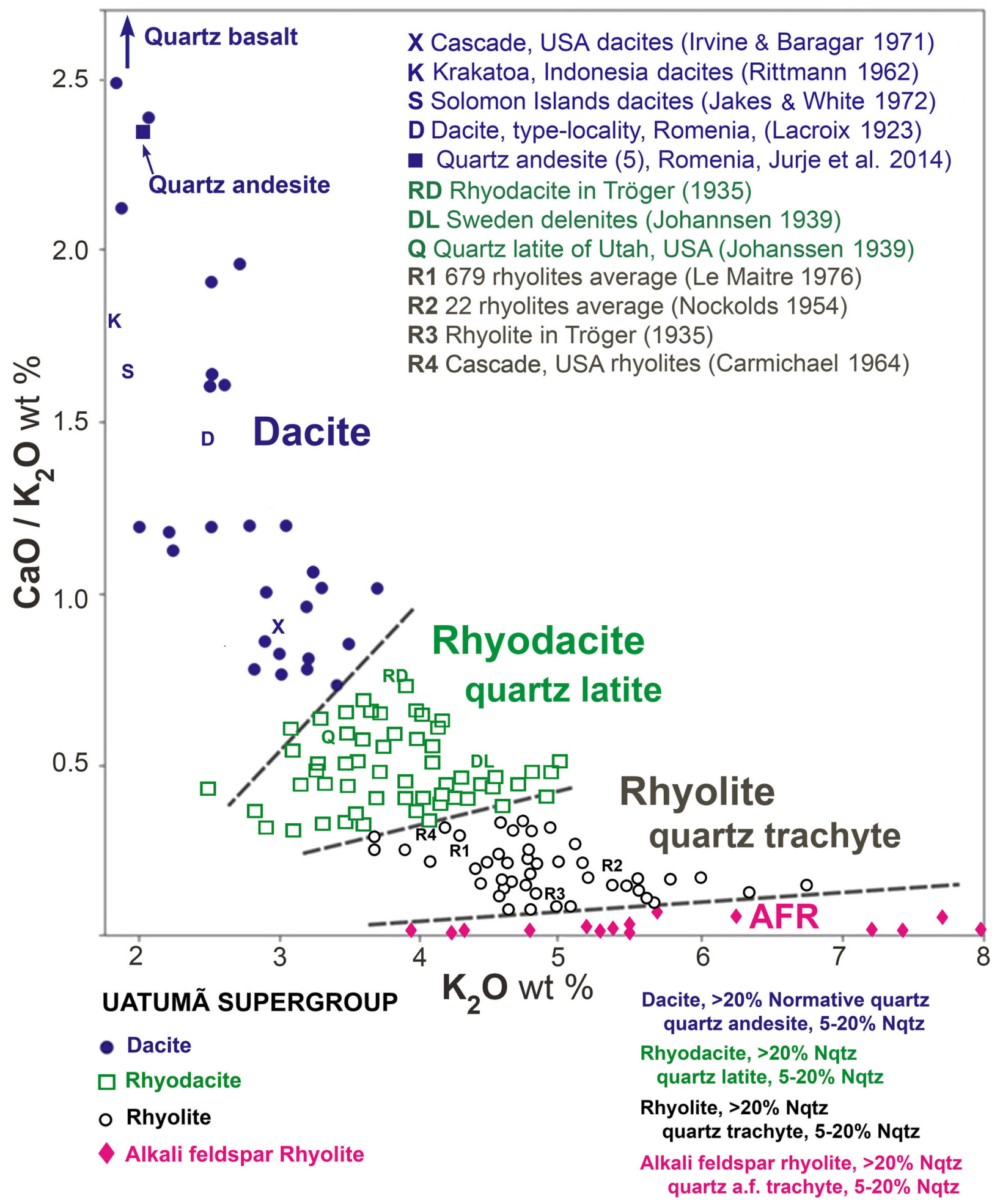

Figure 8. KCK diagram for acid (oversaturated) rocks with distribution of Uatumã volcanic rocks (legend in lower left). Twelve known rock compositions and world averages used to test the diagram are listed in the upper part of the graph. 
The second proposed diagram is dedicated to acid volcanic rocks (alkali feldspar rhyolite, quartz alkali feldspar rhyolite, rhyolite, quartz trachyte, rhyodacite, quartz latite, dacite, quartz andesite, quartz basalt), that is rocks with > $5 \%$ Nqtz. Distribution of points $(n=153)$ also follows a cubic parabola (Fig. 8) similar to Fig. 7 , from less evolved andesite $\left(\mathrm{CaO} / \mathrm{K}_{2} \mathrm{O}=2.5\right)$ to more evolved alkali feldspar trachyte with $8 \% \mathrm{~K}_{2} \mathrm{O}$. Quartz basalt and quartz andesite (oversaturated rocks) are separated from basalt and andesite (saturated rocks) using the 5\% modal and normative quartz limit. The scarcity of consistent data about quartz basalt in the literature restrains the definition of a field for this type of volcanic rock. Based on the $\mathrm{CaO} /$ $\mathrm{K}_{2} \mathrm{O}$ ratios of basalts, we consider that quartz basalts have $\mathrm{CaO} / \mathrm{K}_{2} \mathrm{O}$ ratio well above 2.5 which is the highest value for dacites plotted in Fig. 8. The average of 20 Neogene quartz basalts from the Carpathians (Jurje et al. 2014) has $\mathrm{CaO} / \mathrm{K}_{2} \mathrm{O}$ ratio of 3.95 (at 1.75 wt.\% $\mathrm{K}_{2} \mathrm{O}$ ), plotting above the upper limit of Fig. 8. Quartz andesites also have high $\mathrm{CaO} / \mathrm{K} 2 \mathrm{O}$ ratio, in the same range as andesite (2.1 to 7.2, see Fig. 7). One example of quartz andesite (average of five samples) from the eastern Carpathians, Romenia (Jurje et al. 2014) has $\mathrm{CaO} / \mathrm{K}_{2} \mathrm{O}$ ratio of 2.40 (filled quadrangle of Fig. 8).

The limits between dacite (quartz andesite) - rhyodacite (quartz latite) - rhyolite (quartz trachyte) - alkali feldspar rhyolite (quartz alkali feldspar trachyte), were established based on Uatumã rock types. These limits were tested using 12 known rock compositions, type locality compositions, and world average compositions.

\section{DISCUSSION}

Common volcanic rocks are broadly grouped into four major categories according to the degree of silica saturation understood as the availability of silica (generally quartz), felspathoid, or olivine: acid, intermediate, basic, and ultrabasic rocks (Shand 1947, Yoder \& Tilley 1962). The limits between categories are associated to the mineralogical composition because some minerals are more and others less saturated in $\mathrm{SiO}_{2}$. Therefore, a rock with higher $\mathrm{SiO}_{2}$ (weight \%) may be less saturated than a rock with lower $\mathrm{SiO}_{2}$ in chemical composition; and vice versa.

Three major elements have wide variation among volcanic rocks, from the less evolved (basalt) to the more evolved (rhyolite, trachyte): silica, calcium and potassium. Sodium or $\mathrm{Na}_{2} \mathrm{O}$ has little variation among common volcanic rocks and is not a discriminating element. Besides that, sodium is present in the structure of both plagioclase and alkali feldspar, causing difficulty in the determination of the proportion of $\mathrm{Na}$ in the two minerals. Several diagrams from the literature lack proper allocation of sodium among feldspars and, consequently, have strong potential for misclassification of the rocks.

Presence of $\mathrm{Ca}$ or $\mathrm{CaO}$ is mandatory for any diagram using major elements. Without this oxide/element the proportion of alkali feldspar and plagioclase cannot be established, and the result will be an incorrect classification. The best example of a diagram which is ineffective because of lack of $\mathrm{CaO}$ is the TAS diagram.

Some classification diagrams are based in immobile elements such as zirconium, titanium, and yttrium (Winchester \& Floyd 1977, Pearce 1996) or thorium and hafnium (Wood et al. 1980). Zircon and zirconium are the notorious and most commonly inherited mineral and element in magmatic systems.

Inherited zircon was formed in different magmatic and tectonic settings in relation to the zircon of the target rock (Pidgeon et al. 1996). Other HFS (high field strength) elements may be also inherited such as Ti (titanite; Pidgeon 


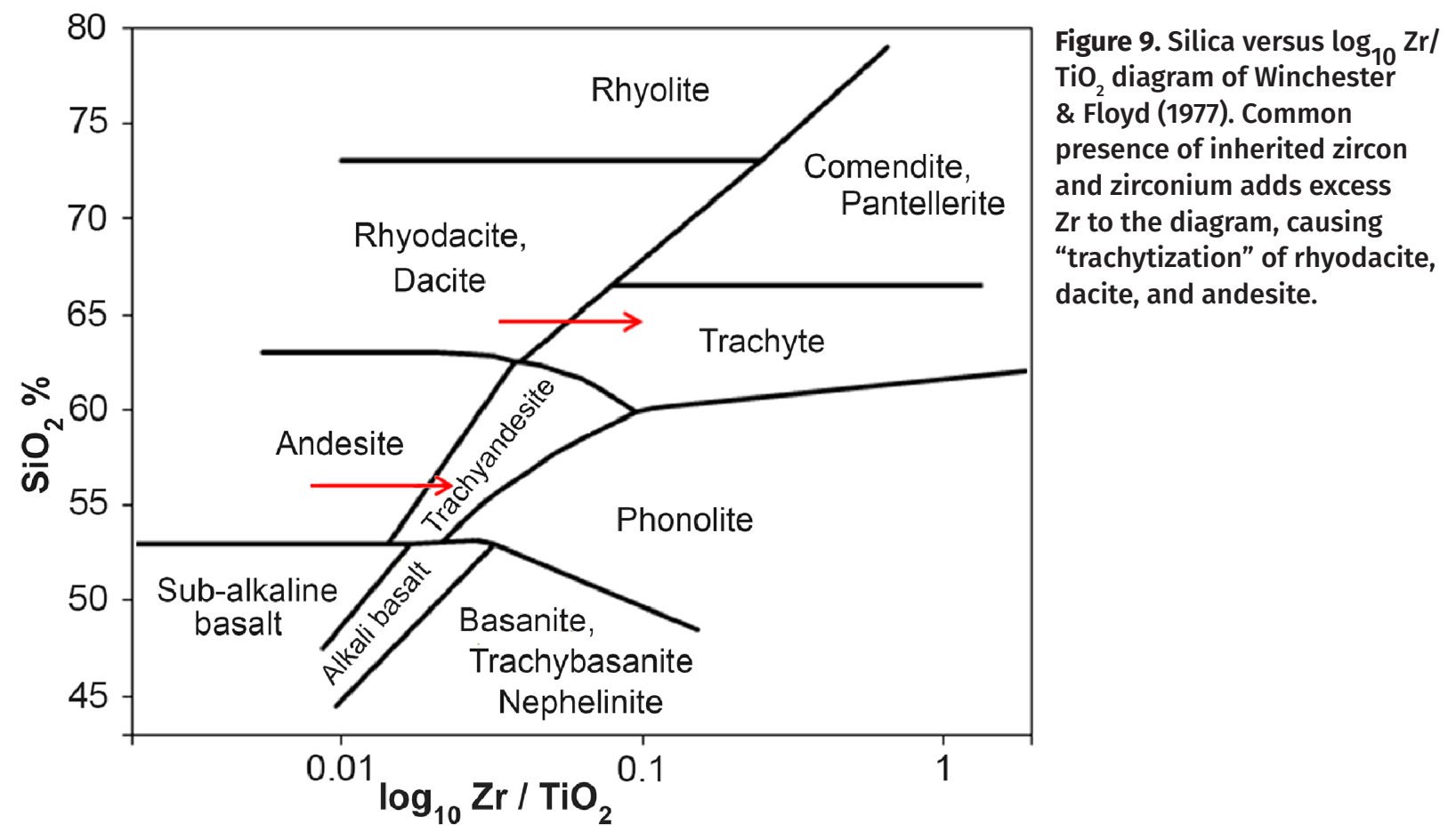

et al. 1996), Th (monazite, Imayama \& Suzuki 2013), Y (xenotime, Miller et al. 1992), and Hf (follows inheritance of zircon). These elements cannot be used or used with great caution in classificatory diagrams because they derive from zircon, xenotime, monazite and titanite, minerals which frequently or occasionally are inherited. Most volcanic rocks have both magmatic zircon and inherited zircon producing an excess of zirconium, which leads to the misclassification of the rock. The common effect of the excess $\mathrm{Zr}$ (magmatic plus inherited) is moving the points plotted on $\mathrm{SiO}_{2}$ versus $\log _{10} \mathrm{Zr} / \mathrm{TiO}_{2}$ diagram (Winchester \& Floyd 1977) to the right causing the artificial trachytization of rhyodacite, dacite, and andesite (Fig. 9).

\section{Some examples of misclassifications using TAS}

Several compositions and names based on TAS diagram are broadly incorrect because they include a number of misclassifications. For example, some published andesites are in fact latite (e.g. Eocene "andesites" of Nevada, samples 49 and 154 of Ryskamp et al. 2008). Those samples have high $\mathrm{K}_{2} \mathrm{O}$ (3.86\% and $4.23 \%$ ) corresponding to excess $\mathrm{K}$-feldspar to be andesite. The contents are even higher than the maximum (3.4\% $\mathrm{K}_{2} \mathrm{O}$ for andesites with $60 \%$ $\mathrm{SiO}_{2}$ ) considered for high-K andesites (Gill 1981). Other number of "andesites" in fact are quartz andesites because they are oversaturated rocks with normative quartz greater than $5 \%$. Examples are from the Cainozoic Kermadec Island, New Zeland (Kemner et al. 2015): 22GTV-5 (15\% Nqtz), 22GTV-4 (11\% Nqtz), and 29GTV-1 (16\% Nqtz). Large numbers of "rhyolites" have more than 2.6\% CaO (e.g. Peate et al. 1992), which results in excess normative plagioclase (from $23 \%$ to $34 \%$ ) to be true rhyolites. All rhyolites of Peate et al. 1999 (table 3, p. 124), from the Lower Cretaceous [Valanginian] Paraná LIP, Brazil, 134-135 Ma according to Pinto et al. (2011), are quartz latite, rhyodacite and dacite. Several dacites (adakites) with Na-plagioclase (oligoclase) are confused with trachytes (e.g. Guo et al. 2007; Miocene, Tibetan Plateau). Twelve trachyandesites of 
northern Iran (Davidson et al. 2004) have high $\mathrm{K}_{2} \mathrm{O}$ content (average $=4.39 \%$ ) representing excess sanidine ( $A=35 \%$ on QAP diagram). They are all latite, not trachyandesite. Literature has many of these and other misclassifications.

\section{CONCLUSIONS}

The studied Uatumã volcanic rocks are from three regions and have a dominance (about $70 \%$ ) of acid over intermediate (30\%) rocks. This contrasts with the pre-Uatumã volcanic rocks of Carajás Province (Sobreiro Formation) which are dominated by intermediate rocks (andesite, basaltic andesite, trachyandesite; Ferreira \& Lamarão 2013). On the other hand, intermediate rocks are scarce among the postUatumã volcanics (1780-1760 Ma) of Colíder Group of South Amazon Craton, which is mainly composed by rhyolite and ignimbrite (Santos et al. 2019).

The presented KCK diagrams are more effective to classify common volcanic rocks than several diagrams from the literature. The application of these two diagrams is to be tested using large datasets and volcanic rocks from different ages and tectonic environments.

The use of a single classificatory diagram to name both saturated (six families) and oversaturated (ten families) volcanic rocks has limitations. Geological literature lacks any diagram capable of classify all rocks correctly. The first step to chemically classify volcanic rocks is to apply the values of normative quartz (Nqtz) to determine the degree of silica saturation and separate the four major groups of rocks: undersaturated, saturated, moderately oversaturated, and oversaturated. Additionally, the return is essential to the classical definition of degree of saturation thus abandoning the proposition (sponsored by the IUGS) which defines the groups of acid, intermediate, basic, and ultrabasic rocks accordingly to their fixed contents of $\mathrm{SiO}_{2}$ at $63 \%, 52 \%$ and $45 \%$.

Several thousand rocks from worldwide published articles from 1980 to present day, all classified using the TAS diagram, need to be checked and part of them reclassified using for example the two proposed KCK diagrams. This is necessary considering that the TAS diagram is not able to identify or classify ten among 16 families of volcanic rocks. The artificial extinction of several volcanic rock-types can thus be avoided, including quartz trachyandesite, latite, quartz latite, quartz trachyte, quartz andesite, quartz basalt, alkali feldspar rhyolite, alkali feldspar trachyte, and rhyodacite, which artificially disappeared to a large extent from the literature.

\section{Acknowledgments}

The Geological Survey of Brazil kindly allowed the use of published and unpublished analytical data from Uatumã volcanic rocks. We are grateful to geologists from the Geological Survey of Brazil regarding extended and deep discussions on the theme, particularly Hilton T. Costi, Josafá R. Oliveira, Manoel R. Pessoa ${ }^{\dagger}$, Wilson Wildner, and Sandoval S. Pinheiro ${ }^{\dagger}$.

\section{List of abbreviations}

CD-ROM, compact disc read-only memory.

CIPW, Cross, Iddings, Pirsson, and Washington.

CPRM, Geological Survey of Brazil.

DNPM, Departamento Nacional de Produção Mineral.

DOI, Digital Object Identifier.

GEOMITEC, Geologia e Mineração, Trabalhos Técnicos Ltda.

GSA, Geological Society of America.

IMA, International Mineralogical Association.

ISBN, International Standard Book Number.

ISSN, International Standard Serial Number.

IUGS, International Union of Geological Sciences.

$\mathrm{KCK}, \mathrm{K}_{2} \mathrm{O}$ versus $\mathrm{CaO} / \mathrm{K}_{2} \mathrm{O}$ ratio.

LAMIN, Mineralogical Laboratory of CPRM. 
LOSIMAG, Low Si and Mg (mantle model).

Mqtz, modal quartz.

MTS, MagnetoTelluric Sounding.

$\mathrm{NCl}$, Normative Colour Index.

NPC, Normative Plagioclase Composition.

Nqtz, normative quartz.

ORCID, Open Researcher and Contributor ID.

PRIMA, Primitive Mantle.

PYROLITE, PYROxenes and OLivine (Upper

mantle model).

QAP, quartz, alkali feldspar, plagioclase.

RADAM, Radar na Amazônia.

SUDAM, Superintendência para o Desenvolvimento da Amazônia.

TAS, total alkali-silica.

UEA, Universidade do Estado do Amazonas.

UFRGS, Federal University of Rio Grande do Sul.

\section{REFERENCES}

AHMADIPOUR H, SABZEHEI M, WHITECHURCH H, RASTAD E \& EMAMI MH. 2003. Soghan complex as an evidence for paleospreading center and mantle diapirism in Sanandaj-Sirjan zone (south-east Iran). I Sci Islam Repub Iran 14(2): 157-172. ISSN 1016-1104.

ALBUQUERQUE OR. 1922. Reconhecimentos geológicos no valle do Amazonas (Campanhas de 1918 e 1919). Boletim do Serviço Geológico e Mineralógico do Brasil, Rio de Janeiro 3: 1-84.

ALLĖGRE et al. 1995. The chemical composition of the Earth. Earth Planet Sci Lett 134(3-4): 515-526.

ALLEN CA. 1986. Mineralization controls and alteration of the Archaean quartz-monzonite-hosted Porphyry gold deposit. B.Sc. Honour thesis, University of Western Australia, Perth, $76 \mathrm{p}$.

ANBARASU K, DAR AM, KARTHIKEYAN A \& PRABHU D. 2011. Field Characteristics and Geochemistry of Pyroxenite and Gabbro from Odhimalai and Thenkalmalai Hillocks of Bhavani Ultramafic Complex- South India. Int Multidiscip Res J 1(2): 20-26. ISSN: 2231-6302.

ARAÚJO HJT, RODARTE JBM, DEL'ARCO JO, SANTOS DB, BARROS AM, TASSINARI CCG, LIMA MIC, ABREU AS \& FERNANDES CAC. 1976. Geologia. In: BRASIL. Departamento Nacional da Produção Mineral. Projeto RADAMBRASIL. Folha SB.20
Purus. Rio de Janeiro. (Levantamento de Recursos Naturais, 17).

BARROS MAS, CHEMALE JR F, NARDI LVS \& LIMA EF. 2009. Paleoproterozoic bimodal post-collisional magmatism in the southwestern Amazonian Craton, Mato Grosso, Brazil: geochemistry and isotopic evidence. I S Am Earth Sci 27(1): 11-23. https://doi.org/10.1016/j.jsames.2008.11.003.

BARTRUM JA. 1937. Interesting xenoliths from Whangarei Heads, Auckland, New Zealand. Transactions of the Royal Society, New Zeland 67: 251-280.

BECKE FJK. 1899. Der Hypersthen-Andesit der Insel Alboran. Tschermaks Mineralogische und Petrographische Mitteilungen. Wien. Vol.18, 2nd Ser, p. 525-555.

BERBELEAC I, ZUGRAVESCU D, RADULESCU V, STANICA D \& NUTU ML. 2004. The structure of Voia Neogene subvolcanic body and related alteration-mineralization in the light of the drilling exploration and MTS data, Romania. Abstract In: Romania Journal of Mineral Deposits 81: 76-79. ISSN 1220-5648.

BERRANGÉ JP. 1977. The geology of Southern Guyana, South America. Institute of Geological Sciences, London, Overseas Division, Mem 4, 112 p. ISBN: 0118807714.

BIZZINELLA GA, SANTIAGO AF, SANTOS A, BORGES FR, SOUZA FJC, GODOY HK, YAMAGUTI HS, OLIVEIRA JR \& OLIVEIRA LR. 1980. Projeto Tapajós-Sucunduri, Relatório Final, partes I e II. Departamento Nacional da Produção Mineral, Companhia de Pesquisa de Recursos Minerais, Manaus, Brasil, vols. la and Ib (in Portuguese).

BOSMA W, KROONENBERG SB, MAAS K \& DE ROEVER EWF. 1983. Igneous and metamorphic complexes of the Guiana Shield in Suriname. Geologie en Mijnbouw 62: 241-254. ISSN: 0016-7746.

BOWEN OE. 1954. Geology and mineral deposits of Barstow quadrangle, San Bernardino County, California. California Division of Mines Bulletin 165: 7-185.

BROWN WL \& WILLAIME C. 1974. An explanation of exsolution orientations and residual strain in cryptoperthites. In: MacKenzie WS \& Zussman J (Eds). The Feldspars, p. 440459. Manchester University Press, U.K.

CARMICHAEL ISE. 1964. The petrology of Thingmuli, a Tertiary volcano in Eastern Iceland. J Petrol 5(3): 435-460. https://doi.org/10.1093/petrology/5.3.435.

CHAYES F. 1966. Alkaline and subalkaline basalts. American J Sci 264(2): 128-145. doi: 10.2475/ajs.264.2.128.

COATS RR, HAY RL \& ANDERSON CA. 1968. Studies in Volcanology. Geol Soc Am Mem 116, 678 p. 
COOMBS DS. 1963. Trends and affinities of basaltic magmas and pyroxenes as illustrated on the diopsideolivine-silica diagram. Mineralogical Society of America Special Paper 1: 227-250.

COX KG, BELL JD \& PANKHURST RJ. 1979. Compositional variation in magmas. In: The Interpretation of Igneous Rocks. Springer, Dordrecht, Netherlands, 455 p. DOI: https://doi.org/10.1007/978-94-017-3373-1_2.

CROSS W, IDDINGS JP, PIRSSON LV \& WASHINGTON HS. 1902. A quantitative chemico-mineralogical classification and nomenclature of igneous rocks. J Geol 10: 555-690.

DALY RA. 1933. Igneous rocks and the depths of the Earth. New York, McGraw-Hill, 598 p.

DAVIDSON J, HASSANZADEH J, BERZINS R, STOCKLI DF, BASHUKOOH B, TURRIN B \& PANDAMOUZ A. 2004. The geology of Damavand volcano, Alborz Mountains, northern Iran. GSA Bulletin 116 (1-2): 16-29. DOI 10.1130/B25344.1.

DE LA ROCHE H, LETERRIER J, GRANDCLAUDE P \& MARCHAL M. 1980. A classification of volcanic and plutonic rocks using R1R2-diagram and major-element analyses - Its relationships with current nomenclature. Chem Geol 29: 183-210. doi.org/10.1016/0009-2541(80)90020-0.

DEBON F \& LE FORT P. 1983. A chemical-mineralogical classification of common plutonic rocks and associations. Trans R Soc Edinb Earth Sci 73: 135-149. DOI: https://doi. org/10.1017/S0263593300010117.

DEER WA, HOWIE RA \& ZUSSMAN JZ. 2013. An Introduction to the Rock-Forming Minerals, $3^{\text {rd }}$ edition. Framework Silicates, Alkali Feldspars $(\mathrm{K}, \mathrm{Na})\left[\mathrm{AlSi}_{3} \mathrm{O}_{8}\right]$ with minor $\mathrm{CaAl}_{2} \mathrm{Si}_{2} \mathrm{O}_{8}$. Mineralogical Society of Great Britain and Ireland, 253-290. https://doi.org/10.1180/DHZ.

FERREIRA ATR \& LAMARÃO CN. 2013. Geologia, petrografia e geoquímica das rochas vulcânicas Uatumã na área sul de São Félix do Xingu (PA), Província Carajás. Braz J Geol 43(1): 152-167. DOI: 10.5327/Z2317-48892013000100013.

FERREIRA EO. 1959. Contribuição à litologia da série Uatumã. Boletim do Serviço Geológico e Mineralógico, Rio de Janeiro 185: 1-31.

GILL JB. 1981. Orogenic andesites and plate tectonics. Springer Verlag Berlin-New York, 392 p. DOI: 10.1007/978-3-642-68012-0.

GILL R. 2010. Igneous rocks and Processes. A practical guide. tectonics. Willey-Blackwell, West Sussex, UK, 428 p. ISBN 978-0-632-06377-2.

GUNN BN, ROOBOL MJ \& SMITH AL. 1974. Petrochemistry of the Peleéan-type volcanoes of Martinica.
Geol Soc Am Bull 85(7): 1023-1030. https://doi. org/10.1130/0016-7606(1974)85<1023:POTPVO>2.0.CO;2.

GUO Z, WILSON M \& LIU J. 2007. Post-collisional adakites in south Tibet: Products of partial melting of subductionmodified lower crust. Lithos 96: 205-224.

HAASE CS, CHADAM J, FEINN D \& ORTOLEVA P. 1980. Oscillatory Zoning in Plagioclase Feldspar. Science 209(4453): 272274. DOI: 10.1126/science.209.4453.272.

HAGOS M, KOEBERL C, KABETO K \& KOLLER F. 2010. Geochemical characteristics of the alkaline basalts and the phonolite -trachyte plugs of the Axum area, northern Ethiopia. Austrian J Earth Sci, Vienna 103(2): 153-170.

HART SR \& ZINDLER A. 1986. In search of a bulk-Earth composition. Chem Geol 57(3-4): 247-267.

HOLUB FV. 2004. Zoned dike of lamprophyre to horblendite near Dobris. Czech Geological Survey, Geosci Res Rep 37: 106-108. ISSN: 2336-5757.

HUANG JG, HAN RS, TAO R \& Li ZQ. 2012. Andesite Geochemistry Features of Late Triassic Tumugou Formation, in Zhongdian, Yunnan Province. Adv Mat Res 16: 524-527. https://doi.org/10.4028/www.scientific.net/ AMR.524-527.16.

IMAYAMA T \& SUZUKI K. 2013. Carboniferous inherited grain and age zoning of monazite and xenotime from leucogranites in far-eastern Nepal: Constraints from electron probe microanalysis. Am Mineral 98(8-9): 13931406. DOI: $10.2138 / a m .2013 .4267$.

IRVINE TN \& BARAGAR WRA. 1971. A guide to the chemical classification of the common volcanic rocks. Can J Earth Sci 8 (2): 523-548. https://doi.org/10.1139/e71-055.

IZBEKOV PE, EICHELBERGER JC, PATINO LC, VOGEL TA \& IVANOV BV. 2002. Calcic cores of plagioclase phenocrysts in andesite from Karymsky volcano: Evidence for rapid introduction by basaltic replenishment. Geology 30(9): 799-802. doi: 10.1007/s00445-0090280-z.

JAGOUTZ E, PALME H, BADDENHAUSEN H, BLUM K, CENDALESM, DREIBUS G, SPETTEL B, LORENZ $\vee \&$ WANKE H. 1979. The abundances of major, minor and trace elements in the earth's mantle as derived from primitive ultramafic nodules. Proc Lunar Planet Sci Conf 10th (1979), p. 2031-2050.

JAKES P \& WHITE AJR. 1972. Major and trace element abundances in volcanic rocks of orogenic areas. Geol Soc Am Bull 83(1): 29-40. https://doi. org/10.1130/0016-7606(1972)83[29:MATEAI]2.0.CO;2. 
JENSEN LS. 1976. A New Cation Plot for Classifying Subalkalic Volcanic Rocks. Ontario Geological Survey Miscellaneous Paper 66, 22 p.

JOHANNSEN A. 1939. A descriptive petrography of the igneous rocks. Chicago University Press, $2^{\text {nd }}$ edition 1 : $318 \mathrm{p}$.

JOHNSON RW, KNUTSON J \& TAYLOR SR. 1989. Intraplate Volcanism: In Eastern Australia and New Zealand. Australian Academy of Science, Cambridge University Press, 408 p. ISBN: 0521380839.

JURJE M, IONESCU C, HOECK V \& KOVACS M. 2014. Geochemistry of Neogene quartz andesites from the Oaş and Gutâi Mountains, Eastern Carpathians (Romania): a complex magma genesis. Mineral Petrol 108(1): 13-32. DOI: 10.1007/ s00710-013-0282-6.

KEMNER F, HAASE KM, BEIER C, KRUM S \& BRANDL PA. 2015. Formation of andesite melts and Ca-rich plagioclase in the submarine Monowai volcanic system, Kermadec arc. American Geophysical Union 16(12): 4130-4152. https:// doi.org/10.1002/2015GC005884.

LACROIX A. 1923. Mineralogie de Madagascar. Challamel, Paris, 3 volumes, $450 \mathrm{p}$.

LE BAS MJ, LE MAITRE RW, STRECKEISEN A \& ZANETTIN B. 1986. A Chemical Classification of Volcanic Rocks Based on the Total Alkali-Silica Diagram. J Petrol 27(3): 745-750. https:// doi.org/10.1093/petrology/27.3.745.

LE MAITRE RW. 1976. The chemical variability of some common igneous rocks. J Petrol 17(4): 589-598. https:// doi.org/10.1093/petrology/17.4.589.

LE MAITRE RW (Ed) ET AL. 2002. Igneous Rocks: A Classification and Glossary of Terms, Recommendations of the International Union of Geological Sciences, Subcommission of the Systematics of Igneous Rocks. Cambridge University Press. ISBN 0-521-66215-X.

MAALФE S. 2005. The dunite bodies, websterite and orthopyroxenite dikes of the Leka ophiolite complex, Noeway. Mineral Petrol 85: 163-204.

MACDONALD GA. 1968. Composition and origin of Hawaiian lavas. Geological Society of America Williams volume, Memoir 116, 477-522. DOI:HTTPS://DOI.ORG/10.1130/ MEM116-P477.

MACDONALD GA \& KATSURA T. 1964. Chemical composition of Hawaiian lavas. J Petrol 5: 82-133. https://doi.org/10.1093/ petrology/5.1.82.

MAIER WD, RASMUSSEN B, FLETCHER IR, GODEL B, BARNES SJ, FISHER LA, YANG SH, HUHMA H \& LAHAYE Y. 2015. Petrogenesis of the $\sim 277$ Ga Monts de Cristal Complex, Gabon: Evidence for Direct Precipitation of Pt-arsenides from Basaltic Magma. J Petrol 56(7): 1285-1308. doi: 10.1093/petrology/ egv035.

MARTEL C, CHAMPALLIER R, PROUTEAU G, PICHAVANT M, ARBARET L, BALCONE-BOISSARD H, BOUDON G, BOIVIN P, BOURDIER J-L \& SCAILLET B. 2013. Trachyte Phase Relations and Implication for Magma Storage Conditions in the Chaîne des Puys (French Massif Central). J Petrol 54(6): 1071-1107. doi:10.1093/petrology/egt006.

MCDONOUGH W \& RUDNICK R. 1998. Mineralogy and composition of the upper mantle. Ultrahigh-Pressure Mineralogy: Physics and Chemistry of the Earth's Deep Interior 37: 139-164.

MCDONOUGH WF \& SUN SS. 1995. Composition of the Earth. Chem Geol 120: 223-253. Doi: 10.1016/0009-2541 (94)00140-4.

MELO AFF, SANTOS AJ, CUNHA MTP, CAMPOS MJF \& D'ANTONA RJG. 1978. Projeto Molibdênio em Roraima: Relatório Final. Companhia de Pesquisa de Recursos Minerais, Departamento Nacional da Produção Mineral, Manaus, Unpublished Report, vols. 1-4 (in Portuguese).

MENDES JC, JUNHO MCB \& GHIZI A. 2004. Diorite and hornblendite enclaves at Sumidouro, RJ, Central Ribeira Belt. Rev Bras Geociênc 34(1): 79-86.

MIDDLEMOST EAK. 1985. Naming materials in the magma/ igneous rock system. Earth Sci Rev 37: 215-224. https:// doi.org/10.1016/0012-8252(94)90029-9.

MILLER CF, HANCHAR JM, WOODEN JL, BENNETT VC, HARRISON TM, WARK DA \& FOSTER DA. 1992. Source region of a granite batholith: evidence from lower crustal xenoliths and inherited accessory minerals. Transactions of the Royal Society of Edinburgh. Earth Sciences 83(12; Second Hutton Symposium: The Origin of Granites and Related Rocks), 49-62. DOI: https:// doi.org/10.1017/ S0263593300007744.

MONTALVÃO RMG, MUNIZ MB, ISSLER RS, DALL' AGNOL R, LIMA MIC, FERNANDES PECA \& SILVA GG. 1975. Geologia da Folha NA.20 Boa Vista e parte das folhas NA.21 Tumucumaque e NB.20-Roraima. In: Brasil, Departamento Nacional da Produção Mineral; Projeto RADAM.

MUKASA SB \& SHERVAIS JW. 1999. Growth of subcontinental lithosphere: evidence from repeated dike injections in the Balmuccia massif, Italian Alps. Lithos 48: 287-316.

NEGENDANK JFW. 1973. Some aspects of volcanic rocks of the valley of Mexico. Bull Volcanol 37: 292-303. https:// doi.org/10.1007/BF02597630.

NEKVASIL H, DONDOLINI A, HORN J, FILIBERTO J, LONG H \& LINDSLEY DH. 2004. The Origin and Evolution of 
Silica-saturated Alkalic Suites: an experimental study. J Petrol 45(4): 693-721. 2004. DOI: 10.1093/petrology/egg103.

NOCKOLDS SR. 1954. Average chemical compositions of some igneous rocks. GSA Bulletin 65(10): 1007-1032. https://doi.org/10.1130/0016-7606(1954)65[1007:ACCOSI] 2.0.CO;2.

O'CONNOR JT. 1965. A classification for quartz-rich igneous rocks based on feldspar ratios. Geological Survey Research, Chapter B, Geological Survey Professional Paper 525-B, p. 79-84.

OLIVEIRA AS, FERNANDES CAC, ISSLER RS, ABREU AS, MONTALVÃO RGM \& TEIXEIRA W. 1975. Geologia. In: BRASIL. Departamento Nacional da Produção Mineral. Projeto RADAMBRASIL. Folha NA.21 Tumucumaque e parte da Folha NB.21. Rio de Janeiro, 370 p. (Levantamento de Recursos Naturais, 9), p. 17-97.

PARAT F, DUNGAN MA \& LIPMAN PW. 2005. Contemporaneous trachyandesitic and calc-alkaline volcanism of the Huerto Andesite, San Juan Volcanic Field, Colorado, USA. J Petrol 46(5): 859-891. doi:10.1093/petrology/egi003.

PEARCE JA. 1996. A User's Guide to Basalt Discrimination Diagrams, In: Wyman DA (Ed). Trace Element Geochemistry of Volcanic Rocks: Applications for Massive Sulphide Exploration: Geological Association of Canada, Shon Course Notes 12: 79-113.

PEATE DW, HAWSKWORTH CJ \& MANTOVANI MSM. 1992. Chemical stratigraphy of the Paraná lavas (South America): classification of magma types and their spatial distribution. Bull Volcanol 55: 119-139.

PEATE DW, HAWKESWORT CJ, MANTOVANI MSM, ROGERS NW \& TURNER SP. 1999. Petrogenesis and stratigraphy of the high-Ti/Y Urubici magma type in the Paraná flood basalt province and implications for the nature of Dupal-type mantle in the South Atlantic region. J Petrol 40: 451-473.

PESSOA MR, SANTIAGO AF, ANDRADE AF, NACIMENTO JO, SANTOS JOS, OLIVEIRA JR, LOPES RC \& PRAZERES WV. 1977. Projeto Jamanxim. Relatório Final. Companhia de Pesquisa de Recursos Minerais, Departamento Nacional da Produção Mineral, Manaus, Unpublished Report, vols. 1-3. (in Portuguese).

PIDGEON RT, BOSCH D \& BRUGUIER O. 1996. Inherited zircon and titanite $\mathrm{U}-\mathrm{Pb}$ systems in an Archaean syenite from southwestern Australia: implications for U-Pb stability of titanite. Earth Planet Sci Lett 141(1-4): 187-198. https:// doi.org/10.1016/0012-821X(96)00068-4.

PINTO VM, HARTMANN LA, SANTOS JOS, MCNAUGHTON NJ \& WILDNER W. 2011. Zircon U-Pb geochronology from the
Paraná bimodal volcanic province supports a brief eruptive cycle at 135 Ma. Chem Geol 281: 93-102.

POTTS PJ \& WEST M. 2000. Portable X-ray Fluorescence Spectrometry: Capabilities for in Situ Analysis. Royal Society of Chemistry Publishing, 292 p. https://doi. org/10.1039/ 9781847558640.

RAMGRAB GE \& SANTOS JOS. 1974. O Grupo Uatumã. In: Congresso Brasileiro de Geologia, Porto Alegre. Anais 2: 87-94.

RENZULUI A, SANTI P, SERRI G \& LUNI M. 2002. The Euganean trachyte flagstones ("basoli") used by the Romans along the mid-Adriatic coast (Marche, central Italy): an archaeometric study Periodico de Mineralogia, Special Issue: Archaeometry and Cultural Heritage 71: 189-201.

RINGWOOD AE. 1979. Origin of the Earth and Moon. SpringerVerlag New York, p. 287. ISBN-13: 978-1-4612-6169-8.

RIOS JH. 1972. Geologia de la region de Caicara, Estado Bolivar. In: Congreso Geológico Venezolano, $4^{\text {th }}$, Caracas, 1971, Memória, Publicación Especial 5 3: 1759-1782.

RITTMANN A. 1952. Nomenclature of volcanic rocks, Bulletin of Volcanology, Series II 12: 76-102. DOI:10.1007/ bf02596015.

RITTMANN A. 1962. Volcanoes and their activity. Translated from the 2nd German Edition by E.A. Vincent. Wiley, New York, $305 \mathrm{p}$.

RITTMANN A. 1973. Stable mineral assemblages of igneous rocks. Berlin Springer Verlag, 262 p. DOI: https://doi. org/10.1017/S0016756800045702.

ROOBOL MJ \& SMITH AL. 1976. Mount Pelée, Martinique: a pattern of alternating eruptive styles. Geology 4(9): 521-524. doi.org/10.1130/0091-7613(1976)4<521: MPMAPO> 2.0.CO;2.

RYSKAMP EB, ABBOTT JT, CHRISTIANSEN EH, KEITH JD, VERVOORT JD \& TINGEY DG. 2008. Age and petrogenesis of volcanic and intrusive rocks in the Sulphur Spring Range, central Nevada: Comparisons with ore-associated Eocene magma systems in the Great Basin. Geosphere 4(3): 96519. doi: 10.1130/GES00113.1.

SANTOS FS, PIEROSAN R, BARROS MAS, GERALDES MC \& LIMA MF. 2019. Petrology of the Colíder Group volcanic successions in the northernmost Mato Grosso, Brazil: A contribution to the knowledge of the felsic volcanism of the Alta Floresta Gold Province. J S Am Earth Sci 89: 10-29. https:// doi.org/10.1016/j.jsames.2018.10.007.

SANTOS JOS. 1984. Classificação química das rochas vulcânicas Uatumã. In: Congresso Brasileiro de Geologia, Rio de Janeiro. Anais 9: 4526-4538. 
SANTOS JOS. 1985. A classificação dos vulcanitos Uatumã. In: $1^{\text {st }}$ Symposium Amazonico, Puerto Ayacucho, Venezuela, 1981, Memoria, Ministerio de Energia y Minas, Dirección de Geologia, Boletín de Geologia 10: 259-272.

SANTOS JOS. 2003. Geotectonics of the Guyana and Central Brazil Shields, chapter IV, p. 169-226. In: Geology, Tectonics and Mineral Resources of Brazil: Text, Maps and GIS. In: Bizzi LA, Schobbenhaus C, Vidotti RM \& Gonçalves JH (Eds). Brasília, CPRM, Serviço Geológico do Brasil, 692 p. ISBN 85-230-0790-3.

SANTOS JOS. 2012. A classificação química de rochas vulcânicas. In: Congresso Brasileiro de Geologia, 45 Belém, outubro de 2012, Paper 236, CD-ROM.

SANTOS JOS, BREEMEN OB, GROVES DI, HARTMANN LA, ALMEIDA ME, MCNAUGHTON NJ \& FLETCHER IR. 2004. Timing and evolution of multiple Paleoproterozoic magmatic arcs in the Tapajós Domain, Amazon Craton: Constraints from SHRIMP and TIMS zircon, baddeleyite and titanite U-Pb geochronology. Precambrian Res 131(1): 73-109. DOI: 10.1016/ j.precamres.2004.01.002.

SANTOS JOS \& RAMGRAB GE. 1974. O Grupo Uatumã. In: Congresso Brasileiro de Geologia, Porto Alegre. Anais 1: 32-33.

SHAND SJ. 1913. On saturated and unsaturated igneous rocks. Geol Mag 10: 508-514. DOI: https://doi.org/10.1017/ S0016756800127700.

SHAND SJ. 1947. Eruptive Rocks. Third edition, 1947. Geol Mag 86(1): 1-360. DOI: https://doi.org/10.1017/ S0016756800074173.

SIAL AN, LONG LE \& BORBA GS. 1987. Field trip guide excursion: Cretaceous Magmatic Province of Cabo, Pernambuco, Northeast Brazil. Rev Bras Geociênc 17(4): 667-673.

STRECKEISEN A. 1976. To each plutonic rock its proper name. Earth Sci Rev 12: 1-33. https://doi. org/10.1016/0012-8252(76)90052-0.

STRECKEISEN A. 1978. IUGS Subcommission on the Systematics of Igneous Rocks: Classification and nomenclature of volcanic rocks, lamprophyres, carbonatites, and melilite rocks: Recommendations and suggestions. Neues Jahrbuch für Mineralogie, Stuttgart, Abhandlungen, Germany 143: 1-14. ISSN 0077-7757.

STRECKEISEN A. 1979. Classification and nomenclature of volcanic rocks, lamprophyres, carbonatites, and melilite rocks. Recommendations and suggestions of the IUGS Subcommission on the Systematics of Igneous Rocks. Geology 7(7): 331-335. https://doi. org/10.1130/0091-7613(1979)7<331:CANOVR>2.0.CO;2.
SUDAM-GEOMINERAÇÃO - SUPERINTENDÊNCIA DE DESENVOLVIMENTO DA AMAZÔNIA. 1972. Pesquisa mineral no Iriri-Curuá: relatório preliminar. GeoMineração Ltda, Belém, A.P.C., Divisão de Documentação, 62 p.

SUDAM-GEOMITEC - SUPERINTENDÊNCIA DE DESENVOLVIMENTO DA AMAZÔNIA. 1972. Pesquisa mineral no TapajósJamanxim: relatório preliminar. GEOMITEC, Geologia e Mineração Trabalhos Técnicos Ltda., 172 p.

SUDAM-GEOMITEC - SUPERINTENDÊNCIA PARA O DESENVOLVIMENTO DA AMAZÔNIA. 1976. Geologia básica, prospecção geoquímica e por concentrados de bateia na região dos rios Tapajós e Maués. GEOMITEC, Geologia e Mineração Trabalhos Técnicos Ltda. Superintendência para o Desenvolvimento da Amazônia, Belém 2: 281 p. (in Portuguese).

TARELOW NETO J, PIEROSAN R, BARROS MAS, CHEMALE JR F \& SANTOS FS. 2017. Magmatic microgranular enclaves of the northeast of Mato Grosso, Brazil, SE Amazonian Craton: Insights into the magmatism of the Uatumã Supergroup, on the basis of field and petrological data. J S Am Earth Sci 78: 61-80. https://doi.org/10.1016/ j.jsames.2017.06.004.

TAYLOR SR \& MCLENNAN SM. 1985. The continental crust; its composition and evolution; an examination of the geochemical record preserved in sedimentary rocks. Blackwell, Oxford, p. 312.

TRÖGER WE. 1935. Spezielle petrographie der Eruptivgesteine. Eine Nomenklatur - Kompendium mit 1. Nachtrag. Eruptivgesteinsnamen Verlag der Deutschen Mineralogischen Gesellschaft, 360 p. ISBN 978-3-510-99099-3.

TURNER HW. 1895. The age and succession of the igneous rocks of the Sierra Nevada. J Geol 3(4): 385-414. https:// doi.org/10.1086/607226.

VASQUEZ ML \& COSTA LTR. 2008. Geologia e Recursos Minerais do Estado do Pará: Sistema de Informações Geográficas-SIG: texto explicativo dos mapas Geológico e Tectônico e de Recursos Minerais do Estado do Pará. Escala 1:1.000.000. Belém, CPRM. http://rigeo.cprm.gov. br/ jspui/handle/doc/10443.

VEIGA JR JP, NUNES ACB, FERNANDES AS, AMARAL JE, PESSOA MR \& CRUZ SA. 1979. Projeto Sulfetos Uatuma. Relatório Final, DNPM/CPRM, Manaus, 7 vol.

YUND RA \& Chapple WM. 1980. Thermal histories of two lava flows estimated from cryptoperthite lamellar spacings. Am Mineral 65(5-6): 438-443.

WADA K. 1985. Magma mixing process of calcalkalic andesites from Funagata volcano. Journal of 
the Japanese Association of Mineralogists, Petrologists and Economic Geologists 80: 467-483.

WASHINGTON HS. 1906. The Roman comagmatic region. Washington DC, Carnegie Institute of Washington 57: 1-199.

WINCHESTER JA \& FLOYD PA. 1977. Geochemical discrimination of different magma series and their differentiation products using immobile elements. Chem Geol 20: 325343. DOI: 10.1016/0009-2541(77)90057-2.

WOOD DA. 1980. The application of a Th-Hf-Ti diagram to problems of tectonomagmatic classification and to establishing the nature of crustal contamination of basaltic lavas of the British Tertiary Volcanic Province. Earth Planet Sci Lett 50: 11-30. https://doi. org/10.1016/0012-821X(80)90116-8.

YODER HS \& TILLEY CE. 1962. Origin of Basalt Magmas: An Experimental Study of Natural and Synthetic Rock Systems. J Petrol 3: 342-532. http://dx.doi.org/10.1093/ petrology /3.3.342.

ZHIGANG X. 1990. Mesozoic volcanism and volcanogenic iron-ore deposits in eastern China. Geological Society of America, Special paper 237, 38 p. DOI: https://doi. org/10.1130/SPE237.

\section{How to cite}

SANTOS JOS \& HARTMANN LA. 2021. Chemical classification of common volcanic rocks based on degree of silica saturation and $\mathrm{CaO} / \mathrm{K}_{2} \mathrm{O}$ ratio. An Acad Bras Cienc 93: e20201202. DOI 10.1590/0001-3765202120201202.
Manuscript received on August 8, 2020;

accepted for publication on February 28, 2021

\section{JOÃO O.S. SANTOS ${ }^{1}$}

https://orcid.org/0000-0001-5524-7949

\section{LÉO A. HARTMANN ${ }^{2}$}

https://orcid.org/0000-0001-7863-5071

${ }^{1}$ Universidade do Estado do Amazonas(UEA), Fundação Universitas de Estudos Amazônicos, Av. Djalma Batista, 3694, Flores, 69050-010 Manaus, AM, Brazil

${ }^{2}$ Universidade Federal do Rio Grande do Sul, Instituto de Geociências, Av. Bento Gonçalves, 9500, 91501-970 Porto Alegre, RS, Brazil

Correspondence to: João Orestes Schneider Santos

E-mail:orestes1@uol.com.br

\section{Author contributions}

João Orestes S. Santos developed concepts, revised literature, gathered data, made drawings and diagrams and wrote the article. Léo A. Hartmann participated in conceptualization, literature review, revision of figures and text, some writing.

(cc) BY 